\title{
Four-to-Three Telecoms Mergers: Substantial Issues in EU Merger Control in the Mobile Telecommunications Sector
}

\author{
Kalpana Tyagi
}

Published online: 1 February 2018

(C) The Author(s) 2018. This article is an open access publication

\begin{abstract}
This article addresses the recent four-to-three telecoms mergers in the EU and factors such as deregulation and convergence that have provided impetus to the accelerated pace of consolidation. It seeks to find an answer to the elusive question: what is the magic that ensures the approval of the European Commission, is it the magic of the number of mobile network operators, or does some other factor exist, such as the magic of remedies? While looking for answers this article employs an inter-disciplinary approach, using insights from law, economics and corporate strategy. It emerges that there is indeed some magic: not an individual piece of magic but instead collective magic of numbers, of the relevant market and of remedies. Effective, clear-cut remedies with a structural dimension, as was the case in $\mathrm{H} 3 \mathrm{G}$ Italy/WIND/JV, ensure the Commission's approval. Failure to submit suitable remedies, as was the case in H3G/Telefónica UK and TeliaSonera/Telenor, led to prohibition decisions and withdrawal of notification, respectively. The article also criticises the circular loop that the Commission is trapped in - with regard to design of remedies in telecommunications mergers - and underscores the need for a more innovative approach to remedial design.
\end{abstract}

Keywords Telecommunications mergers · Merger remedies $\cdot$ H3G Italy/WIND/JV H3G/Telefónica UK · BT/EE · TeliaSonera/Telenor JV · Mavericks · MVNOs

\section{Introduction}

In order to effectively satisfy the increased appetite for multi-play offers the European Union telecoms sector has recently experienced immense mergers and 
acquisitions (M\&As) on two fronts: On the one hand, the four-to-three mobile mergers, and on the other, the fixed/mobile (F/M) integration. ${ }^{1}$ This first part of a two-part article focuses on the four-to-three mobile mergers and remedies. The second part will concentrate on the F/M mergers.

In her address at the 42nd Annual Conference at Fordham Commissioner Vestager said that when it came to telecommunications mergers, there are no magic numbers and as far as design of remedies is concerned, remedies that may effectively alleviate competition concerns in one merger may not prove to be equally effective in another. ${ }^{2}$ She also praised the Danish telecommunications market for its competitiveness and innovativeness. ${ }^{3}$ About a week before she delivered the speech two Danish mobile network operators ("MNOs"), TeliaSonera and Telenor, which had failed to be just as innovative in their design of remedies with regard to their concentration increasing four-to-three merger, withdrew their notification due to the impending risk of a prohibition decision being issued by the European Commission. ${ }^{4}$ Earlier during the year the European Commission (the "Commission") had prohibited a merger between H3G and Telefónica UK, while the UK Competition and Markets Authority (the "CMA") had unconditionally cleared a merger between British Telecom ("BT") and Everything Everywhere ("EE"). Both the mergers involved the United Kingdom market for mobile telecommunications. Shortly thereafter the Commission cleared the H3G Italy/ WIND/JV, a four-to-three merger, after the parties submitted a substantial set of remedies, including a carve-out that ensured the entry to the Italian telecommunications market of Iliad, a French MNO.

Why does the Commission sometimes approve four-to-three mergers while at other times it prohibits them? What is the accepted number of MNOs in a given market? What kind of merger commitments ensure the Commission's approval of a concentration-enhancing merger?

Employing an inter-disciplinary approach, using insights from law, economics and corporate strategy, this article first analyses strategic considerations and technological factors, such as convergence and multi-play offers, which have provided impetus for consolidation in the sector, and then follows that with an indepth analysis of the very different outcomes in the aforementioned three prima facie very similar mergers which the Commission was notified of during the same time-period.

This part of the article is organised as follows. Section 2 offers a brief overview of the technological side and factors such as convergence and multi-play offers that have disrupted the traditional notion of competition and services in the telecommunications sector. Section 3 examines the role of MNOs, Mobile Virtual Network Operators ("MVNOs"), mavericks and network sharing agreements ("NSAs") in promoting innovation-led competition in the sector. Section 4 discusses in detail two sets of three recent mergers, each set experiencing a very dissimilar outcome:

\footnotetext{
${ }^{1}$ Schubert (2016); Manigrassi et al. (2016), pp. 1-2.

${ }^{2}$ Speech by Commissioner Vestager dt. (2015).

${ }^{3}$ Ibid.

${ }^{4}$ TeliaSonera/Telenor/JV (Case M.7419), Commission Decision, [2015] OJ C 316/01.
} 
the first set comprises of three four-to-three mergers which the Commission was notified of during the time of Commissioner Joaquín Almunia; while the second set comprises of the more recent H3G Italy/WIND/JV, H3G UK/Telefónica and BT/EE mergers which the Commission was notified of during the time of Commissioner Margrethe Vestager. Section 5 further develops on the preceding sections, summarising Sect. 4 and, in the process, identifying trends in the assessment of future telecoms mergers and the design of remedies in future telecoms mergers. Section 6 concludes this part of the article.

\section{Convergence and Consolidation in Telecoms}

Traditionally the telecommunications sector was viewed as a natural monopoly that in order to function effectively needed to be subject to sector-specific regulation. ${ }^{5}$ The regulatory approach was eventually replaced by a competition-led approach as the sector experienced two disruptive changes, one technological and the other being the accompanying regulatory change. ${ }^{6}$ Convergence in the telecommunications sector upset the long-established view of assessing the sector as a natural monopoly it transferred the approach from one that required sector-specific regulation to one that was led by well-established principles of competition law. Technological disruption in the form of convergence prompted authorities world-wide to deregulate the sector. In 2002 the European Commission adopted a consolidated "Electronic Communications Package" to accelerate its move towards a "digital, knowledge-led society". 7 In its regulation dated December 2000 the Commission made it mandatory for "incumbent operators" to offer new entrants access to the local copper loop ${ }^{8}$ at reasonable costs on "fair, transparent and non-discriminatory" terms. 9 "The introduction of competition in the market for local copper networks was expected to accelerate the spread and adoption of the Internet across Europe. ${ }^{10}$ Competition and regulatory intervention in the telecommunications sector merits conscientious reflection, as it effectively means balancing short-term price and quantity issues against long-term investment and innovation objectives. ${ }^{11}$ It may not be apparent, but it is true that regulation significantly impacts competition in the telecoms sector, such as by offering access to competitors, as in the case of local loop unbundling. ${ }^{12}$

In late 2016 the Commission proposed the Connectivity Package that, inter alia, seeks to establish a European Electronic Communications Code. From the first

\footnotetext{
5 Speech by Tirole dt. (1999), pp. 4-6; de Streel (2011), pp. 75-76.

${ }^{6}$ de Streel (2011), pp. 77-80 and 84-87; Cave (2004), pp. 30-32; Huveneers and de Streel (2009), pp. 341-342.

7 Popoviü (2010).

8 The Regulation defined the local loop as the physical circuit that connects a subscriber's premises to the main distribution network or an equivalent local facility.

${ }^{9}$ Regulation (EC) No 2887/2000.

10 Ibid.

11 Nenova (2007), p. 185.

12 Speech by Tirole dt. (1999).
} 
Communications Package to the latest legislative proposal of the EU "Connectivity Package", the principles of competition law remain the basis on which the Commission seeks to achieve its strategic objective of ensuring a connected and competitive digital society. ${ }^{13}$ The "Proposal for a Directive 2016" also identifies the steady convergence of the telecommunications, media and Information Technology (IT) sectors and the seamless range of services that it can offer to achieve the single digital market. ${ }^{14}$

Convergence is self-reinforcing in the sense that it receives continuous positive reinforcement from the supply side as well as the demand side. In the multimedia market, for example, a firm's resource- and knowledge-based strategies, as well as convergence on the technological side, have prompted them to bundle and integrate different forms of content - such as sports, soap operas and movies - into one attractive offer, which collectively may be more value added than the individual parts thereof. ${ }^{15}$ On the demand side, likewise, there has been an increased demand for bundled services. Multi-play bundles, particularly the quadruple play consisting of fixed voice, fixed broadband, pay television (Pay-TV) and mobile services, are increasingly in demand. Bundles can be welfare-enhancing for consumers. The UK Office of Communications (Ofcom), for example, found in its 2014 study of the cost and value of telecommunications services in the UK that triple-play services on average cost the consumer $£ 32.12$, compared with $£ 56.16$ (in 2012 prices) for the average standalone equivalent. ${ }^{16}$

It is evident from both the supply-side (the resource-based perspective of a firm $^{17}$ ) as well as the demand-side that such multiple play bundles are a potential strategy ${ }^{18}$ that maximises the welfare of both sides. The observation, although broadly true, merits prudence before one concludes that the strategy is also the more frequently followed one. ${ }^{19}$ The strategy acts along a continuum and, depending on the nuances of the given market concerned, there could be a range of models that a service provider can choose from.

The search for alternative business and revenue models has commenced, as following deregulation and convergence service providers have suffered decreased average revenue per user (ARPU). ${ }^{20}$ In order to improve their margins they started offering multi-play services. ${ }^{21}$ The decline in telecoms retail revenue was

\footnotetext{
13 Proposal for a Directive (2016), p. 3 and 17.

14 Ibid., p. 2, 24.

15 Pagani (2003), pp. 6-8.

16 Ofcom (2014), p. 15.

17 For an appreciation of a firm's "Absorptive Capacity", which is its ability to identify valuable external information and internalise that for commercial success, and associated theoretical and empirical foundations based in transaction cost economics and resource-based view of a firm, see Cohen and Levinthal (1990).

18 Fudenberg and Tirole (1991).

19 Bar (2014).

${ }^{20}$ Groene et al. (2017).

21 See Lee and Lee (2008), pp. 44-53. The authors take an empirical study based on OECD data and find that the triple-play strategy inter alia led to significant increases in the ARPU of telecommunications service providers, though the quadruple-play strategy did not have a substantial impact on ARPU.
} 
increasingly compensated for by increased sales of "mobile handset data, the Internet of Things (IoT), fixed broadband and Internet Protocol Television (IPTV)". ${ }^{22}$ In UK double-play, which refers to the bundling of fixed-line telephony and broadband, bundles are more successful, with an overall subscription rate of 46\%; in France triple-play comprising of telephony, broadband and Pay-TV bundles are more widely accepted, with more than $30 \%$ of households subscribing for those services. $^{23}$

Mixed evidence on the uptake of multi-play offers has also prompted telecoms operators to pursue different M\&A strategies: while some have focused on mobile mergers, others have considered F/M integration.

\section{MNOs, MNVNOs and NSAs: The Process of Dynamic Competition}

At the retail level MNOs and MVNOs are the most effective sources of competition. There are also other service providers, such as branded retailers, but, from the perspective of competition in the market, MNOs and MVNOs are the most effective sources of retail competition. ${ }^{24}$ This section looks at the role of challenger MNOs, MNVOs and different kinds of network sharing arrangements and their role in promoting competition in the sector. This section also assesses whether MVNOs can position themselves as innovative and disruptive competitors at the retail level and whether it is reasonably feasible for them to upgrade themselves to MNOs.

\subsection{MNOs and MVNOs: An Uneasy Tale of Upstream Access and Downstream Competition}

Service providers that own infrastructure and spectrum are known as MNOs. MVNOs, unlike the MNOs, do not have their own infrastructure; instead they negotiate and enter into complex network sharing agreements with the MNOs. This market is often referred to as the "wholesale market for access and call origination on mobile networks", whereby there exists a vertical link between the MNOs that comprise the supply side and the MVNOs which are the demand side. ${ }^{25}$ Wholesale access is an essential input that enables non-MNOs to offer retail services.

Obtaining access to MNOs is a complex process, in which MVNOs and other service providers first invite MNOs to bid for wholesale access contracts. Short-term business objectives and long-term strategic goals, such as optimising the usage of networks without congesting them and the cannibalisation of existing revenues, prompt MNOs to enter into or refrain from bidding. ${ }^{26}$ Due to its strategic objectives

\footnotetext{
${ }^{22}$ Mason Market (2017).

${ }^{23}$ Green (2015).

${ }^{24}$ Hutchison $3 G$ UK/Telefónica UK (Case M.7612), Commission Decision, [2016] OJ C 357/08, at para. 182.

${ }^{25}$ Hutchison 3 G Italy/Wind/JV (Case M.7758), Commission Decision, [2015] OJ C 391/05, at paras. 167 and 214 .

${ }^{26}$ Ibid., at paras. 1836 and 1873.
} 
and short-term operational constraints an MNO may completely refuse to enter into an access agreement or may periodically choose to freeze the network of an MVNO. This total or partial foreclosure strategy can in turn adversely impact the ability of MVNOs to compete effectively at the retail level.

An MVNO, depending on its level of commitment and corporate strategy, may adopt one of the three business models. ${ }^{27}$ First, it may be hosted on the network of an MNO as an enhanced service provider; second, it may choose to be a light, or partial, MNVO; or lastly it may operate as a fully fledged MVNO. ${ }^{28}$ Full, or thick, MVNOs are the most sophisticated of the three, as they typically have their own core infrastructure. Irrespective of the business model an MVNO chooses to adopt, all MVNOs require access to a network, given that even a full MVNO does not have its own radio network access or spectrum. ${ }^{29}$

Alternatively, instead of receiving access from MNOs, MVNOs may also receive access to the network from Mobile Virtual Network Aggregators ("MVNAs") or Mobile Virtual Network Enablers ("MVNEs"). MVNAs and MVNEs are intermediaries that negotiate wholesale contracts for access to network and spectrum with MNOs. They enter into contractual arrangements with MNOs and in turn offer access to MVNOs, without themselves being active in the downstream retail market. They thereby act as pure intermediaries and may facilitate the initial entry of an MVNO in the retail market. ${ }^{30}$

The traditional view of vertical foreclosure saw an upstream market dominated by a monopolist which attempted to foreclose the downstream market and engage in exclusionary conduct. ${ }^{31}$ In the telecoms market oligopoly exists both at the upstream as well as the downstream level. To appropriately model exclusionary behaviour in such a market that market is more appropriately modelled as a twolevel market, both levels of which are oligopolistic in nature. A vertically integrated (VI) monopolist with exclusive control over the infrastructure may prefer to restrict access to downstream firms. However, in the case of competition in a market for wholesale access VI firms face a prisoner's dilemma, ${ }^{32}$ as refusal to offer access may prompt other firms to offer access to downstream players. ${ }^{33}$ Substantial competition between MNOs ensures that they have considerable incentives to enter into reasonable deals with MVNOs. ${ }^{34}$ Considering the importance of effective competition in the upstream wholesale market for access and call origination, to ensure that vertical competition concerns are averted the Commission considers it important to ensure the continuance of "meaningful and effective competition" in

\footnotetext{
27 Lee et al. (2008), pp. 17-19.

28 Ibid.

29 Hutchison $3 G$ UK/Telefónica UK, supra note 24, at para. 181.

30 Ibid., at paras. 210-14.

31 Posner (1976), pp. 171-211.

32 Prisoner's dilemma is a dilemma faced by the parties wherein given a lack of complete and perfect information, both of the parties are unaware of the choice of the other party. Confronted with a dilemma both the parties are likely to choose an outcome which ultimately makes them both worse off.

33 Brito and Pereira (2010), p. 662.

34 French Conseil de la concurrence 2008, at para. 90.
} 
the upstream market. In H3G Italy/WIND/JV the Commission therefore assessed the vertical effects of the transaction, as part of its assessment of the horizontal effects in the upstream wholesale market. ${ }^{35}$ Likewise, in H3G UK/Telefónica UK one of Commission's significant concerns related to the elimination of wholesale competition, which would make the future entry of non-MNOs particularly difficult. $^{36}$

There are different segments of retail customers and each may have a different set of requirements. As we discussed above, while some customers may value a combined value-added bundle of mobile voice and data, others may prefer only mobile, others cheap international call options and yet others may want only bundles of data. Considering the very niche nature, small size and specific requirements of these isolated market segments, MNOs may find it unviable to tap them optimally. MVNOs are able to effectively step in and complement MNOs by offering competitive services to those untapped niche market segments. This meaningfully explains the success of niche MVNOs such as Lycamobile, the world's largest fully fledged MVNO, with an eight-million-strong customer base and operating in 18 countries, it has its own infrastructure, including a call centre that provides services in more than 20 languages. ${ }^{37}$ Lebara mobile, another niche MVNO that targets price-sensitive international call customers, has a well-defined sales and marketing strategy, and has in the past sponsored international cricket deals and music awards. ${ }^{38}$ It receives access from MNOs such as Vodafone, and, like Lycamobile, has a call centre, which provides services in more than 32 languages. Both Lebara and Lycamobile are $€ 1$ billion plus brands and bigger than Tesco Mobile, a mass market MVNO. ${ }^{39}$ In addition to niche MVNOs, there are also mass-market mobile-only and mass-market F/M MVNOs. Mass-market mobile-only MVNOs, such as Asda Mobile and the Post Office in the UK, often cross-sell their mobile services along with other services, such as supermarket shopping and postal services. Mass market F/M MVNOs, such as BT Mobile, offer fixed, voice, broadband and mobile services and look to sell bundles or cross-sell their products. $^{40}$

Of those three types, strategically speaking MNOs may be more willing to sell wholesale access to niche MVNOs, such as Lycamobile, that help them maximise their revenue potential. ${ }^{41}$ MNOs generally view such MVNOs as associates that optimise the utilisation of their infrastructure, rather than as competitors that may potentially cannibalise their margins. ${ }^{42}$

\footnotetext{
35 Hutchison 3 G Italy/WIND/JV, supra note 25, at paras. 213-215.

${ }^{36}$ Hutchison 3G UK/Telefónica UK, supra note 24, at paras. 1811-12 and 2209-10. In this decision different types of MVNOs, service providers, MVNAs and MVNEs were collectively referred to as nonMNOs.

37 Bennett (2013).

38 Garside (2011).

39 Bennett (2013), Garside (2011).

40 Hutchison 3G UK/Telefónica UK, supra note 24, at para. 977.

41 Ibid., at para 442.

42 Bennett (2013).
} 
The mobile telecommunications sector has high entry barriers. Entry as an MNO involves substantial sunk costs and a lengthy time period. MNOs also require access to valuable spectrum, which is scarce and expensive, and need to make considerable investments in developing a radio access network with national coverage. Even new entrant MNOs may find it challenging to enter into arrangements such as NSAs with established MNOs. Restrictive access agreements tend to prevent MVNOs from offering competitive price and data bundles. ${ }^{43}$ Dependence on MNOs means that MVNOs have limited freedom to design their own tariff plans and "meaningfully differentiate their retail services" from their host MNO in terms of quality or technical innovation. ${ }^{44}$ Contractual clauses reduce their incentives to compete effectively. Moreover, the most frequently employed access model in Germany and the UK is the "price-per-unit' agreement wherein MVNOs pay MNOs based on the number of units of services received. ${ }^{45}$ In the Italian telecoms market the contractual agreement between MVNO DIGI and H3G requires DIGI to have at least $20 \%$ of its total traffic as outgoing international traffic for it to enjoy continued access at wholesale tariff rates. ${ }^{46}$ Moreover, MVNOs have limited opportunities to grow, both horizontally as well as vertically. Successful MVNOs generally tend to be acquired by the MNOs that initially offer them wholesale access. ${ }^{47}$

The question then emerges is whether established MVNOs, such as Lycamobile, Lebara and Tesco Mobile, can be effective potential contenders that can upgrade themselves to MNOs. A decision to upgrade and operate as an MNO is dependent on the following factors: firstly, experience with the market (i.e. technical and commercial expertise); secondly, access to the network; thirdly, financial capacity; and finally, a minimum critical mass. Before an MVNO may consider the possibility of upgrading, it is absolutely essential that it acquires a minimum critical customer base that makes its conversion into an MNO a potential profitable strategy. ${ }^{48}$ When attempting to calculate these numbers, the Commission's empirical analysis of the Irish telecoms market merits attention. The merging parties used a "variable cost analysis' to show a market share of $3.8 \%$, i.e. 112,000 Irish mobile users, was the “tipping point' at which an MVNO may find it cost effective to upgrade itself to an MNO. Respondents to the Commission's market test indicated that for calculation of the tipping point not only the variable costs but also CAPEX (Capital Expenditure) and spectrum fees should be included. Liberty Global, for example, calculated that 200,000 subscribers, which approximated to $5 \%$ of the market, was a suitable tipping point. ${ }^{49}$ To facilitate further analysis the Commission eventually adopted the average of those two estimates.

\footnotetext{
${ }^{43}$ French Conseil de la concurrence 2008, at paras. 39 and 47.

44 Hutchison 3G UK/Telefónica UK, supra note 24, at para. 1024.

45 Ibid., at para. 1039.

46 Hutchison $3 G$ Italy/WIND/JV, supra note 25, at para. 869.

47 French Conseil de la concurrence 2008, at para. 83.

48 Grajek and Kretschmer (2012).

49 Hutchison $3 G$ Ireland/Telefónica Ireland (Case No COMP/M6992), Commission Decision, [2014] OJ C264/6, at paras. 946-48.
} 
Even when the minimum "tipping" market share is achieved, an MVNO may require a substantial period of time, from 5 to 10 years, to upgrade itself to an MNO. To be able to effectively compete in the retail market, and to differentiate the products offered, the key is control of a network, as distinguished from mere access to the network. ${ }^{50}$ Offering MVNOs the opportunity to upgrade themselves and to own infrastructure, instead of leasing it on a pay-as-you-go basis, can turn those potential competitors into effective, fully fledged competitors. ${ }^{51}$

In Liberty Global/Base the European Commission considered the possibilities of MVNOs evolving into an effective competitive constraint over time. Liberty Global/Base was a merger between Liberty Global (a Belgian cable operator that offered fixed internet, fixed telephony and cable services and retail mobile telecommunications services as an MVNO) and Base, which was one of the three MNOs in Belgium. ${ }^{52}$ Both Liberty Global's MVNO and Base were aggressive competitors that exerted a significant competitive constraint in the Belgian retail market for mobile telecommunications services. ${ }^{53}$ Even though Liberty Global was dependent on the MNO for access to the network, it exercised an important competitive constraint at the retail level. Base was identified as an aggressive MNO that exercised an important competitive constraint on the other MNOs. The merger was therefore expected to considerably weaken retail competition. To alleviate the Commission's concerns the parties offered a "fix-it-first remedy" of transferring their ownership of Mobile Vikings and Jim Mobile to Medialaan and offering the latter all incidental support, such as access to Base's mobile network, so that Medialaan could in the long run evolve into an effective competitive constraint.

The analysis of and remedies in four-to-three mergers, which is discussed further in Sects. 4 and 5, offers a valuable assessment of an MVNO's potential and limitations with regard to offering meaningful retail competition and over time upgrading itself to an MNO.

\subsection{Mavericks and Competition}

MNOs and MVNOs share a very special relationship, as MNOs want to offer MVNOs access, but only to a limited extent and under a very restrictive set of conditions. MNOs offer wholesale access in order to optimise the use of their available capacity and to maximise their revenues. ${ }^{54}$

It appears that there is a proportional relationship between the size of an MNO and the cannibalisation effect. For smaller players, who may also usually be late entrants to the market, limited market share means that their first priority is optimising the use of their networks and spectrum. As networks are subject to

\footnotetext{
$\overline{50}$ UK Ofcom (2015), at para 1.44.

51 Fauver and Ramanarayanan (2016), p. 74.

52 Liberty Global/BASE Belgium (Case M.7637), Commission Decision, [2016] OJ C141/06, at paras. $7-10$.

53 Ibid., at paras. 235-65.

${ }^{54}$ Hutchison $3 G$ Italy/Wind/JV, supra note 25, at paras. 1226-27.
} 
economies of scale, the smallest of the MNOs (which usually also is the last entrant) in a market generally tends to be a maverick. ${ }^{55}$

When Martin Bouygues entered the French telecoms market, with the Bouygues Telecom MNO, he said, in jest, that he had not purchased a castle for gypsies to take a walk on its lawns. ${ }^{56}$ The oblique reference there was to Bouygues Telecom and MVNOs, respectively. But it was not long before the very telecoms company that had disdained MVNOs was helping their growth in the French telecoms market. Bouygues was not only disruptive as it soon started offering MVNOs access to its infrastructure on much more competitive terms than those offered by other MNOs, its contractual clauses were also much less restrictive, which offered MVNOs greater flexibility with which to meet the requirements of retail customers. That, in turn, prompted other MNOs to relax their existing contractual conditions. ${ }^{57}$ For very similar reasons, Base, the smallest MNO in Belgium, offered MVNOs access to its infrastructure on incredibly promising contractual conditions. That prompted the migration of MVNOs from other MNOs to Base. Competition from Base prompted the other, more established, MNOs, such as Proximus and Mobistar, to offer access on more favourable terms. ${ }^{58}$

In H3G Italy/WIND/JV the Commission's analysis indicated that even though H3G had a modest market share, its impact was influential, as it more willingly offered access to "mass-market non-MNO entrants", unlike O2 and Vodafone, which were more selective and offered access only to niche non-MNOs. ${ }^{59}$

Interestingly, the very presence of a maverick can be a key driver of competition. In wholesale markets MVNOs invite MNOs to participate in bids and auctions. The bidding nature of markets means that even in the bidding processes where $\mathrm{H} 3 \mathrm{G}$, an important competitive constraint in the UK mobile market, merely participated, without actually winning them, it played an important role. ${ }^{60}$ In its opinion Ofcom pointed out that the $\mathrm{H} 3 \mathrm{G}$ UK/Telefónica UK merger was expected to adversely impact the parties' incentives to offer wholesale access, as it could generate greater cannibalisation effects. Therefore even in cases where $\mathrm{H} 3 \mathrm{G}$ would have otherwise offered access the merged parties would refuse to do the same. ${ }^{61}$

These late, and smallest, entrants therefore play a disruptive role in two of the fundamental relevant markets that usually are also most vulnerable to anticompetitive effects: the market for retail telecommunications and the market for wholesale access to the network and call termination. ${ }^{62}$

According to the Horizontal Merger Guidelines (HMG), some firms may be more effective competitive forces than their market shares may indicate. The loss of such

\footnotetext{
55 Bourreau and Dogan (2001), p.173.

56 See de Launay (2014), « Je me suis acheté un château, ce n'est pas pour laisser les romanichels venir sur les pelouses. ».

57 French Conseil de la concurrence 2008, at paras. 94-95.

58 Ibid. in para. 93.

59 Hutchison $3 G$ Italy/Wind/JV, supra note 25, at paras. 1920 and 1969-70.

${ }^{60}$ Hutchison 3G UK/Telefónica UK, supra note 24, at paras. 2028-29 and 2036-42.

61 Ibid., at paras 2204 and 2209-10.

62 French Conseil de la concurrence 2008, at para. 94.
} 
a firm as a result of a merger may adversely affect competition due to the loss of such an important competitive force. ${ }^{63} \mathrm{~A}$ new entrant is usually more innovative than the incumbent players, which can be explained by the varied incentives of the two sets of operators. ${ }^{64}$ Furthermore, depending on the amount of force exerted, a firm may be considered to be an important competitive force or a maverick. In $\mathrm{H} 3 \mathrm{G}$ Italy/WIND/JV the Commission described $\mathrm{H} 3 \mathrm{G}$ as "an important competitive force" that contributed "substantially and consistently" to the process of competition in the Italian telecoms market on the basis of "price, quality, choice and innovation". 65

The significance of important competitive constraints" can be appreciated by noting the fact that even in mergers which involved other MNOs but were expected to otherwise adversely impact the competitive position of a maverick, the notifying parties had to offer commitments to eliminate those anti-competitive effects. The 2010 merger between T-Mobile and Orange was expected to adversely impact the RAN-sharing joint venture between $3 \mathrm{UK}$ and T-Mobile. ${ }^{66}$ It was expected to marginalise $3 \mathrm{UK}$, a maverick in the UK mobile telecommunications market and the concentration was therefore viewed as a five-to-three merger (and not a five-to-four merger). ${ }^{67}$ To alleviate the concerns the parties offered to sign a new agreement with $3 \mathrm{UK}$ that contractually offered clarity and a commitment to promptly complete the integration of networks. The amended agreement was also significant in the respect that it did not have a termination clause. ${ }^{68}$ The commitments, though nonstructural in nature, highlight the importance attached to mavericks and the role of network sharing agreements (NSAs) in promoting infrastructure-led competition. This article will turn to NSAs next.

\subsection{Network Sharing Agreements}

MNOs often have complex network sharing arrangements that are imperative for dynamic, infrastructure-led competition. Moreover, the associated financial budget for deploying an NSA is so high that often even MNOs need to share the cost of developing and maintaining an NSA. They, therefore, enter into complex NSAs. Considering the role of NSAs in the promotion of dynamic, infrastructure-led competition, the Commission has been particularly concerned about the adverse impact of telecoms mergers on NSAs. In H3G UK/E-Plus the merger was expected to decrease "industry-wide investments [in] network infrastructure". 69 As the notifying parties were members of two different NSAs, after the merger they could

\footnotetext{
${ }^{63}$ EU Merger Regulation 2004, para 37.

64 Bourreau and Dogan (2001), p.177.

65 Hutchison $3 G$ Italy/WIND/JV, supra note 25, at paras. 432-433 and 437-438.

66 T-Mobile/Orange (Case No COMP/M.5650), Commission Decision, [2010] OJ C108/03, at paras. $80-85$.

67 Ibid., at para. 106.

68 Ibid., at paras. 204-13.

69 Hutchison $3 G$ UK/Telefónica UK, supra note 24, at para. 1233.
} 
more closely align the industry-wide investment strategy with their own by withholding further investments in either or both of those networks. ${ }^{70}$

Mutual co-dependence in NSAs means that for the effective and optimum functioning of the networks the partners must have aligned interests and strategies. ${ }^{71}$ Each of the members of a network has veto power, which means that if one of the partners refuses to invest further in the network the subsequent development of infrastructure is prevented. In H3G UK/Telefónica Ireland, therefore, the Commission was concerned that the adverse impact on the NSA between H3G UK and Eircom could lead to the subsequent marginalisation of the latter.

Furthermore, these complex agreements may, based on the level of the parties' commitment, be active, passive or fully fledged agreements. Alternatively, the parties may opt to participate together in spectrum auctions and use that spectrum jointly to optimise their costs and the usage of the valuable resource (i.e. the spectrum). Depending on the type of NSA, the MNOs involved benefit from a range of $\mathrm{CAPEX}^{72}$ and $\mathrm{OPEX}^{73}$ cost savings. ${ }^{74}$ Passive infrastructure may involve only the sharing of communication towers, in which the MNOs can place their own active equipment. ${ }^{75}$ In the Italian market, for example, Infrastructure Wireless Italian S.p.A ("INWIT"), the largest operator by number of sites and tenancy ratio, offers simultaneous passive access to all of the Italian MNOs. ${ }^{76}$

In recent mergers the Commission has gone a step further and considered whether more active NSAs can be an effective alternative to promote investment-led competition. In $\mathrm{H} 3 \mathrm{G} / \mathrm{WIND} / \mathrm{JV}$ the notifying parties claimed that consolidation would bring significant impetus to investment-led competition. The Italian market was, at that time, characterised by passive sharing agreements only. ${ }^{77}$ As a counterfactual to the merger the Commission assessed whether the parties could alternatively enter into active NSAs, and found that the latter was likely to generate more benefits and revenue synergies. ${ }^{78}$ It was found that active sharing, particularly active Long-Term Evolution technology (LTE) sharing, would yield efficiencies equivalent to the proposed JV without generating any associated anti-competitive concerns. $^{79}$

The observation merits qualification, as NSA arrangements, though generally less troublesome than mergers, present their own set of problems. NSAs can, for example, negatively affect infrastructure-led competition if the strategic objectives

\footnotetext{
${ }^{70}$ Ibid., at para. 1287.

71 Ibid., at para. 1234.

72 CAPEX refers to Capital Expenditure such as the cost of acquisition of fixed assets and undertake new projects and investments. They can be considered as sunk costs.

73 OPEX are the Operating Expenses incurred in the course of daily operations. These are the equivalent of variable costs.

74 Hutchison 3G Italy/WIND/JV, supra note 25, at paras. 97-113.

75 Ibid., at paras. 106-09.

76 Ibid., at paras. 110-13.

77 Ibid., at paras. 100.

78 Ibid., at paras. 1582-94.

79 Ibid., at paras. 1615-30.
} 
of the network-sharing partners differ. As each member of the NSA enjoys a veto power, refusal to any subsequent proposals (such as further investments and network upgrades) by even one of the members of a network means that the deal may collapse completely. This means that the members of a network need to be unanimous on each and every subsequent proposal to ensure its successful implementation. If even a single member rejects an upgrade or change, that may restrict further development. ${ }^{80}$ NSAs can also present other competition concerns, such as co-ordinated effects. That can, for example, be the case with a four-MNO market which has two network sharing agreements, given that in such a situation it is easy for the MNOs to monitor deviations and effectively punish the deviating member. In such a market there is also a distinct possibility of "industry-wide coordination to refuse to supply MVNOs". ${ }^{81}$ In an active NSA parties need to regularly share sensitive information relating to network capacity and usage. Access to sensitive information can lead to collusive outcomes. ${ }^{82}$ To prevent that an effective regulatory requirement, such as mandatory Chinese walls which prevent marketing and commercial teams from receiving access to technical information, is just as paramount in the case of an NSA-led mobile market as in the case of a concentration-enhancing merger. ${ }^{83}$ Additionally, the nature of the telecommunications sector is such that it offers its players numerous opportunities to interact in multiple settings, giving them the opportunity to co-ordinate and soften conditions of competition. Bilateral inter-connection, standard-setting and infrastructuresharing agreements are some of the ways in which they can "interact, retaliate and collude" not only on price but also on strategic aspects, such as design of networks and choice of technology, thus affecting dynamic competition adversely. ${ }^{84}$

\section{Recent Four-to-Three Mergers: Similar Telecoms Mergers, Dissimilar Outcomes}

Between 2012 and 2014 the European Commission conditionally approved three four-to-three mergers: H3G/Orange Austria; H3G Ireland/O2; and Telefónica Deutschland/E-plus. This was during the term of Joaquím Almunia as EU commissioner for competition. In late 2014 a new commission was appointed and Margrethe Vestager replaced Almunia as the commissioner for competition. The start of her term was greeted by the notifications of three four-to-three mergers across the EU: TeliaSonera/Telenor JV; H3G UK/Telefónica UK; and H3G Italy/ WIND/JV. Considering the consistent approach followed by the commissioners during their terms, and the substantial difference between their respective

\footnotetext{
80 Schubert (2016).

81 OECD (2015), p. 69; Rey (2004), pp. 27-28.

82 Hutchison 3G UK/Telefónica UK, supra note 24, at paras. 1293-97, 1737-42 and 1784-85. In this case, however, the Commission's theory with regard to harm was reduction in incentives to invest and not co-ordination effects.

83 OECD (2015), p. 70; Rey (2004), pp. 27-28.

${ }^{84}$ Rey (2004), pp. 28-30.
} 
approaches, in this section these mergers are categorised in two groups and the emerging analytical framework assessed with regard to four noteworthy issues: theories of harm; use of quantitative tools; assessment of mavericks; and design of remedies in telecoms mergers. Section 4.1 presents the approach in H3G/Orange Austria, H3G Ireland/O2 and Telefónica Deutschland/E-plus, which are summarised in Sect. 4.1.4; Sect. 4.2 addresses TeliaSonera/Telenor JV, H3G UK/Telefónica UK and H3G Italy/WIND/JV, which are summarised in Sect. 4.2.4.

\subsection{H3G/Orange Austria, H3G Ireland/O2 and Telefónica Deutschland/E-plus}

This section looks at three four-to-three mergers (H3G/Orange Austria, H3G Ireland/O2 and Telefónica Deutschland/E-plus) that received conditional clearance during the term of Commissioner Almunia. The mergers concerned three very important and highly competitive markets in the EU: Austria, Ireland and Germany. Of particular noteworthiness in these three mergers is the innovativeness of the design of merger remedies.

\subsubsection{Theory of Harm and Use of Quantitative Techniques}

H3G/Orange Austria involved the acquisition of Orange by H3G. The other two MNOs in the market were Telecom Austria (with its A1 brand) and T-Mobile. H3G and Orange were identified as "close competitors' with regard to pricing and tariff structures as well as the ranges of smartphones and data services offered. The Commission used evidence from surveys, market data and econometric simulations to assess the closeness of competition between them. Gross upward pricing pressure index (GUPPI ${ }^{85}$ was used for the first time in a phase-II merger analysis to assess the impact of a concentration on retail mobile prices. Overall the evidence indicated that the merger would lead to significant unilateral effects. ${ }^{86}$

In Telefónica Deutschland/E-Plus Telefónica Deutschland acquired sole control over E-Plus, leading to the creation of the third-largest MNO in terms of overall retail revenues. ${ }^{87}$ The merger led to there being three MNOs of equal size in the German mobile telecommunications market, the other two being Deutsch Telekom and Vodafone. ${ }^{88}$ The merger was expected to significantly impede effective competition, as it generated non-co-ordinated effects in the retail market for mobile telecommunications and wholesale market for access and call origination and international roaming. ${ }^{89}$ Merger simulations, market investigations and internal documents indicated that Telefónica and E-Plus were "close competitors". ${ }^{90}$ The

\footnotetext{
${ }^{85}$ GUPPI is a quantitative technique used to assess the incentives of a merged entity, in the absence of any synergies, to unilaterally increase prices following a merger.

${ }^{86}$ Hutchison $3 G$ Austria/Orange Austria (Case COMP/M.6497), Commission Decision, [2013] OJ C224/ 12, at paras. 175-249.

87 Telefónica Deutschland/E-Plus (Case M.7018), Commission Decision, [2015] OJ C086/7, at para. 254.

88 Ibid., at paras. 211-13.

89 Ibid., at paras. 102-03.

90 Ibid., at paras. 232-320.
} 
Commission's quantitative analysis was based on the "Bertrand Nash model in a differentiated products industry", whereby firms compete in a differentiated products industry and set prices at a level that maximises their profits. ${ }^{91}$ Upward Pricing Analysis (UPP) and "demand estimation-based simulation" indicated that the merger would not only intensify the merged parties' incentives to increase prices, it would also induce competitors to increase their retail prices. ${ }^{92}$

Hutchison 3G UK/Telefónica Ireland (O2) was a merger between $\mathrm{O} 2$ (the second largest MNO) and $\mathrm{H} 3 \mathrm{G}$ (the last MNO entrant and a "challenger brand") to create the second-biggest MNO in the Irish mobile market and generating substantial unilateral effects in the retail and wholesale market. ${ }^{93}$ Eircom and Vodafone were the other two MNOs active in the Irish market.

\subsubsection{Loss of a Maverick and "Market Stabilisation"}

In $\mathrm{H} 3 \mathrm{G} /$ Orange Austria H3G was identified as a "modern, innovative" MNO that had in the past disrupted the market by being the first to offer various innovative services, had the best network quality, offered aggressive price-based competition and followed a data-focussed strategy. ${ }^{94}$ The disappearance of $\mathrm{H} 3 \mathrm{G}$ was expected to result in "stabilisation of the market" and, absent substantial efficiency gains, to result in diminished incentives for $\mathrm{H} 3 \mathrm{G}$ to continue competing aggressively in the market. $^{95}$ Quantitative evidence indicated that $\mathrm{H} 3 \mathrm{G}$ was a more significant competitive force than its market share showed. ${ }^{96}$ After the merger it was unlikely that a new MNO could enter the Austrian market in the short term. ${ }^{97}$ MVNOs that could "discipline prices at the retail level" were far and few in between, as the incumbent MNOs had raised "artificially high barriers to entry" by "protecting their retail business through high wholesale access fees" and, in some instances, outright refusal to enter into wholesale negotiations with MVNOs. This overall resulted in an enormous "market failure". 98 Additionally, to operate as an MVNO in Austria potential entrants either required "access to the portability database", which involved substantial investment and a lengthy period of time, or, alternatively, needed to enter into an access agreement with an existing MNO. ${ }^{99}$ Considering that Orange was the "only" one of the four MNOs to offer that service, in the absence of suitable remedies, after the merger it was highly unlikely that an MNO, or even an MVNO, could enter the market. ${ }^{100}$

\footnotetext{
91 Ibid., Annex A: The Commission's Quantitative Analysis, Section 2 Common Framework: BertrandNash Competition in Differentiated Products, at para. 17.

92 Ibid., paras 736-72.

93 Hutchison $3 G$ Ireland/Telefónica Ireland, supra note 49, at paras. 47 and 62-65.

94 Hutchison 3G Austria/Orange Austria, supra note 86, at paras. 254-65.

95 Ibid., at paras. 283-84.

96 Ibid., at paras. 264-65.

97 Ibid., at paras. 293-94.

98 Ibid., at paras. 295-98.

99 Ibid., at para. 299.

100 Ibid., at para. 300.
} 
In Telefónica Deutschland/E-Plus, where MVNOs and service providers enjoyed a significant market presence, the Commission was of the opinion that MVNOs could potentially over time upgrade themselves to MNOs. Competitive assessment indicated that the dependence of those fringe players on MNOs to receive wholesale access, as well as the prevalent pay-as-you-go model, diminished their incentives to engage in aggressive retail competition. ${ }^{101}$

In $\mathrm{H} 3 \mathrm{G}$ UK/Telefónica Ireland H3G was identified as an important competitive constraint. It had in the past offered various disruptive offers at the retail level, such as "all-you-can-eat" data plans that offered unlimited data packages under certain specific conditions. That had prompted competitors to come up with equally attractive bundles. The merger was expected to eliminate this important competitive constraint and generate the much needed "market equilibrium". Elimination of $\mathrm{H} 3 \mathrm{G}$ was expected to weaken the pressure on $\mathrm{O} 2$ as well as diminishing the competitive pressure on the other MNOs. At the wholesale level $\mathrm{H} 3 \mathrm{G}$ and $\mathrm{O} 2$ competed aggressively to offer access to the MVNOs. Vodafone offered MVNOs access to its networks to a limited extent. Eircom was further subject to hold-up problems due to the adverse impact on its NSA with $\mathrm{H} 3 \mathrm{G}$, which meant that in the near future it had limited ability to offer access to MVNOs. Reduced competition at the wholesale level was further expected to devitalise competition at the retail level. ${ }^{102}$

\subsubsection{Merger Remedies}

The Commission cleared H3G/Orange Austria upon the submission of the following remedies. The parties entered into an upfront MVNO agreement with UPC that ensured its entry as a full MVNO. ${ }^{103}$ The parties also offered to provide wholesale access on competitive terms and conditions to up to 16 MVNOs over the next 10 years to more than $30 \%$ of H3G's network capacity. ${ }^{104}$ To resolve any incidental disputes a fast-track dispute resolution mechanism was proposed. ${ }^{105} \mathrm{H} 3 \mathrm{G}$ also offered to divest $2 \times 10 \mathrm{MHz}$ of spectrum in the $2600 \mathrm{MHz}$ frequency band (the divestment spectrum) to a new entrant. ${ }^{106}$ That spectrum - which was best for the provision of $4 \mathrm{G}$ services - was reserved to be sold alongside a forthcoming spectrum auction by Telekom-Control-Kommission (the "TCK"), the Austrian telecoms regulator. The merger was conditional upon the sale of Orange's Yesss! Telekommunikation subsidiary to A1 Telekom Austria, that sale being subject to the jurisdiction of the Austrian competition authority, the Bundeswettbewebsbehörde. $\mathrm{H} 3 \mathrm{G}$ also offered to sell spectrum and some assets to A1. Those incidental transactions were subject to review by the TCK. ${ }^{107}$

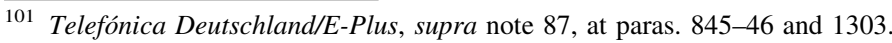

102 Hutchison 3G Ireland/Telefónica Ireland, supra note 49, at paras. 179-86.

${ }^{103}$ Hutchison 3G Austria/Orange Austria, supra note 86, at paras. 520-21.

104 Ibid., at paras. 522-25.

105 Ibid., at para. 547.

106 Ibid., at para. 526.

107 Bavasso and Long (2012).
} 
In Telefónica Deutschland/E-Plus the parties offered a package of commitments consisting of three components: an MNO remedy, a mobile bitstream access (MBA) remedy and a non-MNO remedy. ${ }^{108}$ Under the MNO remedy the parties were to enter into an MNO agreement with a potential entrant and if no potential entrant agreed to enter the market, they were to enter into an agreement with an upfront MBA MVNO. ${ }^{109}$ According to the commitment a new MNO entrant or an MVNO was to be provided with offers regarding: a lease for $10 \mathrm{MHz}$ of paired spectrum in the $2.6 \mathrm{GHz}$ band, national roaming, access to sites and passive radio access network sharing. ${ }^{110}$ The MBA remedy had two components: an obligatory purchase commitment and an optional capacity commitment. Under the obligatory commitment Telefónica was to offer at least one upfront MBA MVNO 20\% of the total capacity (for each of data, voice and SMS) of its network according to a specified glide path. The MBA MVNO also had an option to purchase an additional capacity, equal to another $10 \%$, on similar terms and conditions. ${ }^{111}$ In the non-MNO remedy the notifying party offered to remove any contractual restraints that restricted migration of customers from one MNO to another as well as any restrictions that prevented MVNOs from switching their business models. The parties also offered to enter into wholesale contracts with new MVNOs and service providers. ${ }^{112}$

In $\mathrm{H} 3 \mathrm{G}$ UK/Telefónica Ireland the parties offered commitments that sought to reinstate the loss of competitive constraint exerted by $\mathrm{H} 3 \mathrm{G}$ and to "preserve the premerger state of competition in the market". ${ }^{113}$ As part of the MVNO entry commitment the parties offered to enter into an "upfront capacity agreement" at a fixed price with a pre-approved MVNO. The upfront MVNO was to be offered the option to acquire 48, a sub-brand of $\mathrm{O} 2$ or its customer base. ${ }^{114}$ The parties also offered to enter into "good faith negotiations" with a potential second MVNO during the "MVNO Entry Period". If they failed to enter into a capacity agreement during that period, the divestiture trustee had the authority to offer the capacity for allocation to all potential MVNO entrants at a pre-agreed minimum price. ${ }^{115}$ Under the final MNO commitment, the parties offered the upfront MVNO or the second MVNO an option to acquire five blocks of spectrum in the very attractive 1800, 2100 and $900 \mathrm{MHz}$ spectrums. The MVNOs had a 10-year period in which to enter into negotiations with the merged entity. To be eligible to buy that spectrum the MVNOs had to satisfy the monitoring trustee that they had a concrete business plan to effectively deploy the same. ${ }^{116}$ Following an acquisition of spectrum the acquiring MVNO had the freedom to roll-out its own network, in accordance with its commercial objectives, and in the interim transitional period it could also benefit

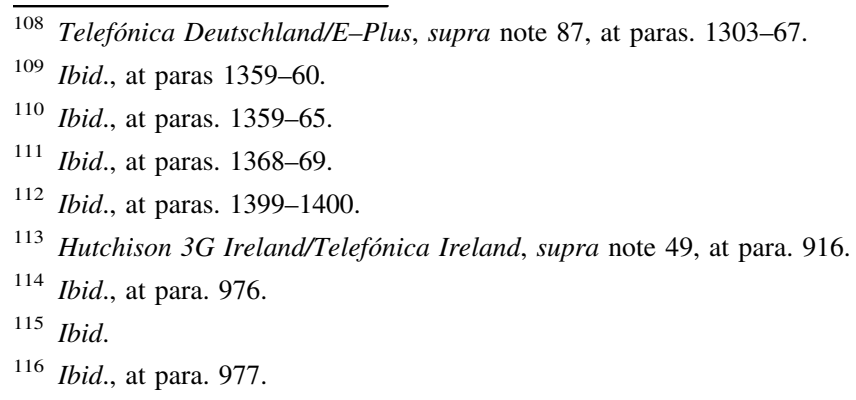


from a respective capacity agreement with the merged entity. ${ }^{117}$ As part of the "final Eircom commitment" the parties offered to amend the existing "Mosiac NSA" in accordance with a memorandum of understanding submitted along with the final commitments. ${ }^{118}$ This offered Eircom two options: either it could conclude a new strengthened NSA or it could enter into an alternative NSA with Vodafone, the other MNO in Ireland. ${ }^{119}$

\subsubsection{Summary}

In all the three mergers "unilateral effects" were identified as the principal theory of harm. H3G UK/Telefónica Ireland is particularly noteworthy, as it did not lead to the creation or strengthening of a (single) dominant position but was nonetheless expected to result in a significant impediment to effective competition (SIEC) in the retail mobile market and the wholesale market for network access and call origination. ${ }^{120}$ This is reflective of the "effects-based approach" of the Commission under the 2004 Regulation, which closed the legislative gap for assessment of unilateral effects as it had existed in the previous 1989 Regulation. ${ }^{121}$

As was noted in Sect. 2, ever since the onset of deregulation the achieving of a "single digital market" has been the preferred goal of the Commission. H3G/ Orange Austria was identified as a trend-advancing certainty in the Commission's efforts to achieve the "single telecoms market", as it expected MNOs to first consolidate in national markets and then inorganically develop a presence in other Member States. ${ }^{122}$

During the term of Commissioner Almunia the Commission pursued that objective and showed some consistent trends in its assessment of four-to-three telecoms mergers and a very innovative approach in the design of remedies.

The remedies reflect the special attention devoted to the somewhat complex relationship between MNOs, MVNOs and NSAs. Of particular noteworthiness is the impressiveness of the remedial design in Telefónica Deutschland/E-Plus and H3G UK/Telefónica Ireland, where each one of the challenges in this complex relationship, as discussed in Sect. 3 above, are well addressed. The remedies take due account of the challenges associated with restrictive access agreements and restricting contractual clauses that limit the ability of MVNOs to compete aggressively at the retail level. Additionally, the remedies also take due account of entry barriers, such as the substantial time period, access to spectrum, incentives to compete and the critical customer base that an MVNO must have in order to over time upgrade itself to an MNO.

\footnotetext{
117 Ibid.

118 Ibid., at paras. 901 and 978.

119 Ibid., at paras. 1007-1011.

120 Ibid., at paras. 179-86.

121 Lindsay and Berridge (2012), pp. 42-55.

122 Stoyanova-Sieber (2013), pp. 432-33.
} 


\subsection{TeliaSonera/Telenor JV, H3G UK/Telefónica UK and H3G Italy/WIND/JV}

This section focuses, along similar lines as in Sect. 4.1 above, on three more recent four-to-three mobile mergers (TeliaSonera/Telenor JV, H3G UK/Telefónica UK and $\mathrm{H} 3 \mathrm{G}$ Italy/WIND/JV), which the Commission was notified of during the term of new Commissioner Vestager, and tries to identify emerging trends for future telecoms mergers.

\subsubsection{Theory of Harm and Use of Quantitative Techniques}

The proposed joint venture between TeliaSonera and Telenor combined the secondand third-largest MNOs in the Danish market. ${ }^{123}$ TeliaSonera and Telenor were also members of a common network sharing agreement, TT-netværket. The merger was expected to lead to a duopoly between TDC and TeliaSonera/Telenor and the marginalisation of $\mathrm{Hi} 3 \mathrm{G}$, an effective competitive constraint in the Danish market. ${ }^{124}$ The Commission worked closely with the Danish competition authority to carry out a customer survey to identify the preferences of marginal customers. ${ }^{125}$ This robust and reliable data was then used to quantify the post-merger price effects through a demand-estimation-based merger simulation. ${ }^{126}$

H3G UK/Telefónica UK was a merger between the second- and fourth-largest MNOs in terms of revenue and number of subscribers, respectively, covering together more than $40 \%$ of all mobile customers in the UK. O2 was also the largest supplier of wholesale access to non-MNOs. ${ }^{127}$ The merger was expected to have adverse horizontal effects on the retail market for the provision of mobile telecommunications services and the market for wholesale access and call origination on public mobile telephone networks in the UK. Diversion ratios indicated that the merging parties were viewed as the best alternatives for one another, ${ }^{128}$ considering that the other two MNOs (Vodafone and EE) were traditionally known to focus on "value generation and customer retention". ${ }^{129}$ The merger also had adverse vertical effects on the retail market for the provision of mobile telecommunications services (the downstream market) and the wholesale market (the upstream market). ${ }^{130}$ The four MNOs participated in complex intertwined NSAs: while EE and H3G were members of Mobile Broadband Network Limited (MBNL), Vodafone and Telefónica were members of the Beacon arrangement. The merger was expected to adversely affect at least one of the two

\footnotetext{
123 TeliaSonera/Telenor/JV, supra note 4.

124 Thomas (2015).

125 Marginal customers should be differentiated from core customers. It is argued that following price increases marginal customers are most likely to switch to substitute products and services.

126 Competition Merger Brief 3/2016, p. 5.

127 Hutchison 3G UK/Telefónica UK, supra note 24, at para. 115.

128 Ibid., at paras. 461-66.

129 Ibid., at para. 953.

130 Ibid., at paras. 306-07.
} 
NSAs. ${ }^{131}$ The complexity of the NSAs meant that contractual undertakings would not be sufficient to solve these problems. The merger reduced the incentives for Vodafone and BT/EE to invest in networks and, therefore, adversely affected investment-led competition. ${ }^{132}$

At the time of the notification of $\mathrm{H} 3 \mathrm{G}$ Italy/WIND/JV the Italian telecommunications market had four MNOs (H3G Italy, WIND, Vodafone and TIM) alongside a number of MVNOs. ${ }^{133}$ The merger adversely influenced competition in the market for the provision of retail mobile telecoms services and wholesale services for access and call origination on mobile networks. ${ }^{134}$ The loss of $\mathrm{H} 3 \mathrm{G}$ as an important competitive force increased symmetries in the market shares of the remaining MNOs and enhanced the post-merger alignment of incentives and the ability to monitor, observe and punish deviation from co-ordination, which meant that following the merger the MNOs could "co-ordinate and raise prices in a sustainable way". ${ }^{135}$ The merger was also likely to lead to non-co-ordinated effects on competition in the wholesale market. ${ }^{136}$ To assess the "closeness of competition" between WIND and H3G the Commission used various tools, such as market investigation, internal documents and diversion ratios. ${ }^{137}$

\subsubsection{Loss of a Maverick and "Market Stabilisation"}

In H3G UK/Telefónica UK both qualitative as well as quantitative evidence indicated that $\mathrm{H} 3 \mathrm{G}$ was an "important competitive constraint" that prompted competitors to offer aggressive subscriptions at cheaper rates. ${ }^{138} \mathrm{H} 3 \mathrm{G}$ had in the past offered many innovative offers, such as an extremely disruptive data monetisation and roaming proposition that offered the ability to "stay connected while travelling without the risk of bill shock". The offer was so disruptive that, despite its small size, H3G had generated a "disproportionate impact on the market" and the other MNOs had been forced to respond with equally competitive offers. ${ }^{139}$ It also offered $4 \mathrm{G}$ services at "no extra cost". The other three MNOs had previously positioned $4 \mathrm{G}$ as a premium service. The offer generated a price war and led market analysts to describe $\mathrm{H} 3 \mathrm{G}$ as a "disruptor-slash-gadfly". ${ }^{140}$ In addition to retail competition H3G also disrupted wholesale competition, as it not only offered access to all types of MVNOs, including mass-market MVNOs, but it had also created its own global MVNE platform that promised to offer wholesale access and end-to-end services to MVNOs. ${ }^{141}$

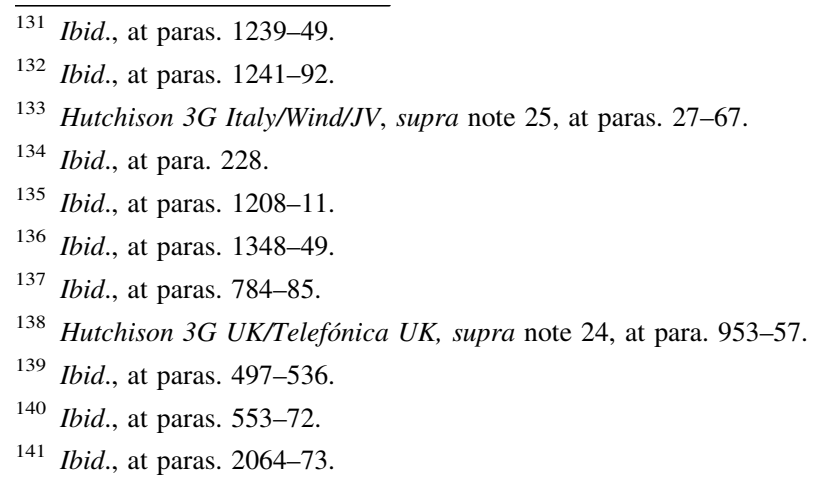


In H3G Italy/WIND/JV, being the smaller of the four players, WIND and H3G had been particularly aggressive in their pricing policies. That had in turn generated immense competitive pressure on the other MNOs to match them with equally attractive offers. The removal of $\mathrm{H} 3 \mathrm{G}$ as an independent competitor was expected to align the incentives of MNOs and to increase their ability to engage in co-ordinated conduct on a sustainable basis. ${ }^{142}$

With the Italian retail market being an oligopolistic market with high barriers to entry, the loss of competition between $\mathrm{H} 3 \mathrm{G}$ and WIND was expected to result in "market repair", ${ }^{143}$ meaning that after the merger H3G/WIND JV, TIM and Vodafone would "compete less aggressively" against one another. ${ }^{144}$

\subsubsection{Merger Remedies}

In TeliaSonera/Telenor the Commission's investigation lasted for more than seven months, with two rounds of remedies submitted by the parties. ${ }^{145}$ The remedies included, inter alia, access for a new market entrant to almost " $40 \%$ of [the parties'] joint infrastructure". ${ }^{146}$ The Commission found that the remedies were insufficient to alleviate the adverse impact on competition. Seeing no hope of receiving the Commission's approval the notification was eventually withdrawn by the parties. ${ }^{147}$

In H3G UK/Telefónica UK the proposed remedies consisted of four principal components: (1) the Tesco Mobile commitment; (2) the new entrant operator ("NEO") commitment; (3) the network sharing commitment; and (4) the wholesale market commitment. ${ }^{148}$ The parties offered to divest O2's stake in Tesco Mobile so as to create an independent MVNO. ${ }^{149}$ The NEO commitment was an upfront commitment to offer access to $\mathrm{O} 2$ 's network, in the form of a "perpetual fractional network interest", so as to facilitate the entry of an NEO. ${ }^{150}$ Tesco Mobile and the NEO were to be offered access to a percentage of the joint network capacity of $\mathrm{O} 2$ and H3G. ${ }^{151}$ NEO was to be offered a capacity-based wholesale access, which was similar to the cost structure of the MNOs and, thereby, expected to maximise the NEO's incentives to compete by optimally utilising the available capacity. According to the network sharing commitment the parties were to implement a "network integration plan" whereby the parties were to commit to using a certain fixed percentage from the Beacon grid and MBNL sites on a regular basis. The parties also committed to have firewalls in place with respect to the two NSAs. ${ }^{152}$ In case of disputes concerning

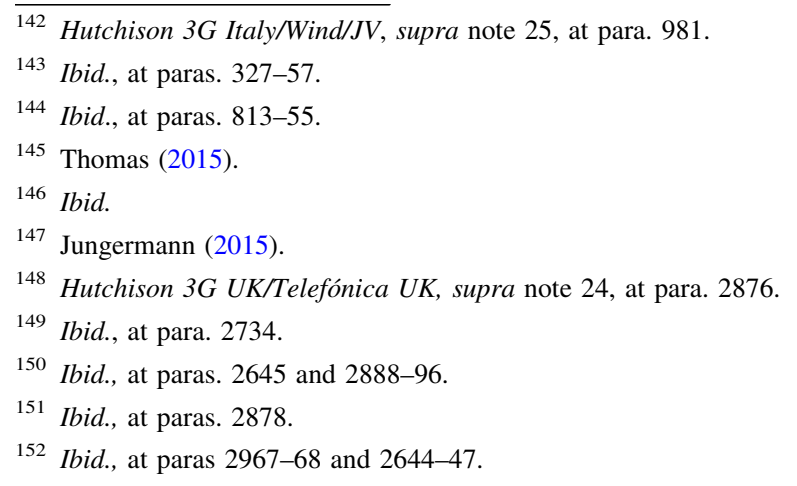


"investment-related decisions" in the MBNL NSA agreement or the NEO commitment, the parties proposed a fast-track dispute resolution procedure. ${ }^{153}$ The wholesale market commitment offered an equivalent "quality of service", as well as 4G and 5G services, to MVNOs. With regard to their existing MVNO customers the Parties committed to offer $4 \mathrm{G}$ and $5 \mathrm{G}$ services at the same rate as they charged for $3 \mathrm{G}$ services. ${ }^{154}$ However, the Commission found the commitments to be insufficient to effectively alleviate its competition concerns and decided to prohibit the merger.

In $\mathrm{H} 3 \mathrm{G}$ Italy/WIND/JV the parties proposed a fix-it-first remedy in which Iliad, an active MNO in the French market, agreed to purchase the divested assets and spectrum. The MNO commitment specified in detail the spectrum to be divested, the procedure and timeline for divestment, the sites to be divested, and the pricing model to be used for offering access to the network. ${ }^{155}$ It also offered the new MNO entrant an option to enter into an RAN-sharing agreement which ensured immediate coverage of the least populated areas in a cost-effective manner. ${ }^{156}$ Moreover, there were no contractual restrictions on the new MNO offering wholesale access to MVNOs. ${ }^{157}$ In the short run the new MNO was offered an attractive pricing model, which ensured that it could offer wholesale access to MVNOs at very competitive terms from the outset. ${ }^{158}$ In the long run it was expected that the new MNO would make "significant progress in rolling out its own network". 159

\subsubsection{Summary}

In TeliaSonera/Telenor, pending the Commission's investigation, Commissioner Vestager, in an interview with the Financial Times, observed that the reaction of the stock market was an indicator of potential post-merger anti-competitive effects. ${ }^{160}$ Stock market data had been previously used in prominent econometric studies to evaluate the effectiveness of EU merger control. ${ }^{161}$ Interpretation of signals and the response of the stock market can be viewed as a step forward in utilising more quantitative techniques in EU merger control.

In addition to unilateral effects, in this second set of four-to-three mergers vertical anti-competitive effects and potential co-ordinated effects are also assessed in great detail, in H3G UK/Telefónica UK and H3G Italy/WIND/JV, respectively. The text in Sect. 3 (supra) presents the principles of industrial organisation (IO) and game theory ${ }^{162}$ and makes clear the conditions under which a vertically integrated

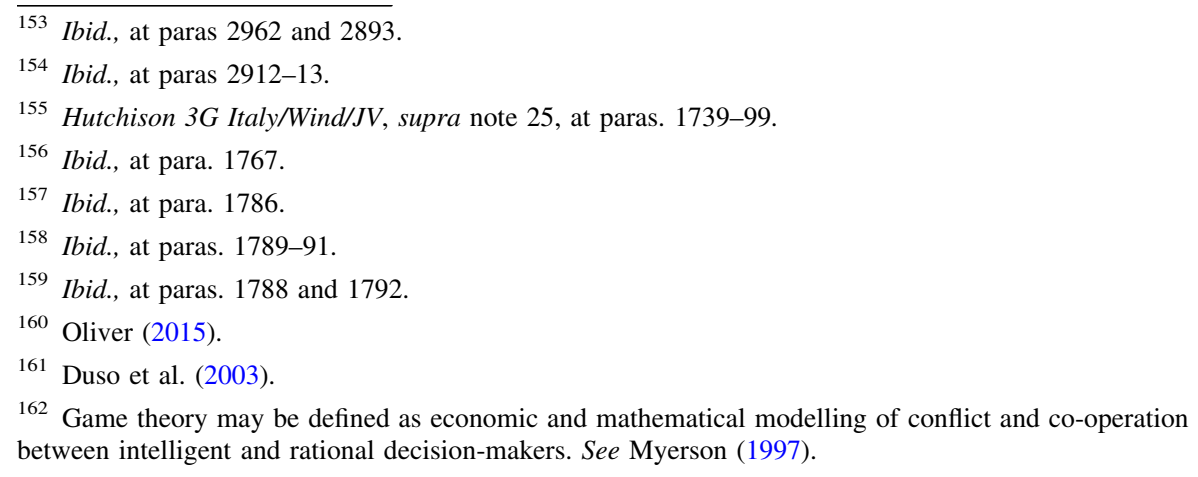


oligopolist may refuse to offer access to downstream competitors and the circumstances under which an oligopoly is likely to exhibit co-ordinated conduct.

With regard to $\mathrm{H} 3 \mathrm{G} \mathrm{UK} /$ Telefónica $\mathrm{UK}$, to make the discussion comprehensive and well-rounded, reference must be made to the UK CMA's decision in BT/EE. The CMA, following a detailed phase-II inquiry, unconditionally cleared the BT/EE merger: a merger between BT, the largest supplier of fixed-line services and other telecommunications services, including an MVNO; and EE, an MNO. Before the merger BT's MVNO was hosted on EE's network. The parties' activities in the provision of retail mobile and fixed communications services overlapped. BT also had a TV network and EE had recently launched a TV network that was expected to compete with BT's. ${ }^{163}$ The CMA considered ten theories of harm, of which eight were studied in significant detail. It assessed the impact of the transaction on the supply of wholesale mobile services, and investigated whether the merged BT/EE could engage in total or partial foreclosure, and reached the conclusion that, even though the merged entity had the ability to harm fixed MVNOs by not bidding for wholesale access or by engaging in input foreclosure of rival MNOs for managed fibre mobile backhaul services or customer foreclosure for MBNL, the presence of four MNOs limited its incentives to engage in either input or customer foreclose. ${ }^{164}$ The conglomerate effects in the context of F/M bundling were also assessed: the CMA was of the opinion that the merger did not offer BT a unique competitive advantage that the other telecoms operators could not replicate. ${ }^{165}$ As the BT/EE merger was not expected to result in substantial lessening of competition in the retail or wholesale mobile market, the merger received unconditional clearance. In its assessment of the $\mathrm{H} 3 \mathrm{G}$ UK/Telefónica UK merger the European Commission took due account of the CMA's decision in BT/EE.

What is particularly intriguing is that even though both of those mergers concerned the same relevant market, i.e. the market for mobile telecommunications in the UK, and even though the Commission was notified of H3G UK/Telefónica before BT/EE was referred to the CMA and H3G UK submitted substantial remedies to obtain the Commission's approval, whereas BT/EE was approved unconditionally by the CMA, the European Commission prohibited H3G UK/ Telefónica UK. The inordinate delay in the Commission's assessment of H3G UK/ Telefónica and the Commission taking due account of the CMA's decision in BT/ EE raises questions with regard to substantial aspects of EU merger control. The approach is plainly inconsistent with the Commission's own recent approach when assessing two recent HDD $^{166}$ mergers (Samsung/Seagate and Western Digital/ Hitachi). The Commission was notified of those mergers almost simultaneously, with notification regarding the former being provided on 19 April 2011 and the latter on 20 April 2011. The Commission, following the "priority-based principle", first assessed and unconditionally cleared Samsung/Seagate without even issuing a

\footnotetext{
163 Jungermann (2015).

164 UK CMA, BT/EE, at paras. 14.28 and 14.45 .

165 Ibid., at paras. 16-17.

166 HDD refers to Hard Disk Drive. HDDs are magnetic data storage and retrieval devices to store digital information. See Arpaci-Dusseau and Arpaci-Dusseau (2014).
} 
statement of objections to the merging parties. ${ }^{167}$ Western Digital/Hitachi was assessed subsequently and, following a detailed phase-II review, received conditional clearance. Clearly the unconditional clearance of Samsung/Seagate had a substantial impact on the Commission's assessment of Western Digital/Hitachi. At the time consistency and coherence in the application of merger control was cited as a reason for the application of priority-based ruling. ${ }^{168}$

Non-conformity with its own prior practice - particularly when the two sets of mergers belong to a similar, if not the same, industry, i.e. ICT and telecommunications - reflects an inconsistency in the Commission's approach. H3G UK/ Telefónica UK is currently pending appeal before the General Court. ${ }^{169}$

In $\mathrm{H} 3 \mathrm{G}$ Italy/WIND/JV the dependence of MVNOs on MNOs for access and restrictive MVNO clauses meant that they could not effectively replace the loss of an MNO. ${ }^{170}$ Similar issues were identified in the three cases discussed in Sect. 4.1 above. Worthy of note is the difference in the remedial approaches to comparable competition concerns in these two sets of telecommunications mergers, an issue which this article looks at next.

\section{Summary and Emerging Trends}

This section outlines emerging trends for future telecoms mergers. Firstly the section presents some challenges that merit further research with regard to non-coordinated or unilateral effects and mavericks (Sect. 5.1) and, secondly, the elusive magic number of MNOs and designs for remedies in telecoms mergers (Sect. 5.2).

\subsection{Unilateral Effects and Mavericks}

For non-co-ordinated effects to arise the merging parties should compete closely in the relevant market. The more closely they compete, the more likely, and to a greater extent, the merger is likely to reduce the competitive pressure. ${ }^{171}$ Two issues merit attention: one is the use of qualitative techniques for a finding of unilateral effects; the other is that in the EU it suffices when the parties are one another's close competitors. ${ }^{172}$ That standard is much lighter when compared with the US standard, where for a finding of a unilateral effect the parties need to be one another's "closest competitors". In both sets of the cases described in Sects. 4.1 and 4.2 unilateral effects have been identified on the basis of "closeness of competition".

\footnotetext{
167 Seagate/HDD Business of Samsung (Case COMP/M.6214), Commission Decision, [2011] OJ C154/ 08, at paras. 6-11.

168 Western Digital/Hitachi (Case COMP/M.6203), Commission Decision, [2011] OJ C241/11, at paras. $31-44$.

169 GC, Case No. T-399/16, CK Telecoms UK Investments Ltd v European Commission (Currently Pending Appeal).

${ }^{170}$ Hutchison 3G Italy/WIND/JV, supra note 25, at paras. 865-899.

171 EU Horizontal Merger Guidelines 2004, at paras. 17, 26 and 28-30.

172 Buettner (2016), p. 692.
} 
In all of the cases discussed above the Commission identified a new or the latest player as the maverick. Economic theory suggests that this behaviour exists due to the "excess capacity" of the new entrant and lasts during the period of transition. It may be referred to as the "tatônnement process", as the entry of a new player disrupts the prevailing equilibrium and the market participants try, collectively, to reach a "new focal point". ${ }^{173}$ Additionally, in four of the six cases discussed above $\mathrm{H} 3 \mathrm{G}^{174}$ was identified as the maverick. This makes one wonder whether "mavericklike" behaviour is a conscious business strategy of $\mathrm{H} 3 \mathrm{G}$ and it may actually be pursuing the Commission's long cherished objective of bringing about the single telecoms market. Inter-disciplinary research, with inputs from economics and corporate strategy, may offer valuable insights into the behaviour of mavericks such as $\mathrm{H} 3 \mathrm{G}$. That can in turn offer valuable insights for competitive assessment of mavericks in telecoms mergers.

\subsection{The Magic Number of MNOs and the Magic of Remedies}

As regards what the optimum number of MNOs in a given market is, as noted by Commissioner Vestager, there are no magic numbers. During the term of Commissioner Almunia that number appeared to be three, with many four-to-three mergers receiving conditional clearance. During the term of Commissioner Vestager that number appears to be four. The approach of the competition authorities is also significantly influenced by the size of the relevant geographic market. In this regard, the approach of national competition authorities (NCAs) merits attention. In Switzerland, considering the size of the market, where four MNOs would be practically impossible to sustain, and two operators could lead to collective dominance, the Swiss Competition Commission (the Wettbewerbsbehörde) found three to be the optimum number and prohibited a three-to-two merger between Orange and Sunrise. ${ }^{175}$ The Swiss Commission's analysis indicated that the merger would lead to the loss of a maverick as well as a position of collective dominance for the merged parties and Swisscom in the retail market and the market for wholesale access - a competitive harm that could not be alleviated by any set of remedies. ${ }^{176}$ This argument finds support in a study of the French mobile market, where the French competition authority (the Autorité de la concurrence) noted that even when the strict conditions of Airtours/Firstchoice were not met, there was sufficient evidence that indicated a collective interest of the MNOs in a three-MNO market to refrain from offering wholesale access to MVNOs on favourable terms. ${ }^{177}$ In H3G UK/Telefónica UK, as discussed above, the CMA and Ofcom in their submissions to the European Commission consistently maintained the position that

\footnotetext{
173 Rey (2004), pp. 102-103.

174 This article consistently refers to Hutchison $3 \mathrm{G}$ as $\mathrm{H} 3 \mathrm{G}$ in order to highlight the role of the parent company CK Telecoms UK Investments Ltd in pursuing a uniform disruptive strategy across the European Union. H3G currently operates under the brand name "Three" or "3".

175 Swiss Competition Commission, France Télécom SA/Sunrise Communications AG, at para. 429.

176 Ibid., at para 428.

177 French Conseil de la concurrence 2008, at paras. 22 and, 98.
} 
four was the magic number of MNOs required to preserve the competitiveness of UK mobile market.

An OECD study on network sharing observed that even though four-MNO markets are generally more competitive, there is no actual "golden number" of MNOs that can ensure competitive markets. It is the "intensity of competition" that is the key to competitive markets. In Portugal, which is a three-MNO market, consumers have in the past benefited from many disruptive offers, such as a "premium roaming offer", on account of aggressive retail competition. ${ }^{178}$ Economic theory suggests that the prisoner's dilemma that eventually prompts MNOs to offer wholesale access to MVNOs is evident in a market with three or more MNOs, where the additional revenue effects far outweigh the competitive constraint imposed by an MVNO. ${ }^{179}$ In a market with three or more MNOs, MNOs voluntarily offer wholesale access to MVNOs under both the Cournot and Bertrand model of competition. ${ }^{180}$ Overall, whether three, four or three and a half is the optimum number remains a debatable issue, both from the perspective of competition policy and economics.

Recent decisions of the Commission underscore that its decisions are influenced significantly by what it seeks to achieve from the remedies. As is shown in Sect. 4 above, the major differentiating factor in terms of the Commission's approach in the two sets of mergers has been with regard to design of remedies.

Commissioner Almunia cleared many four-to-three mergers when the parties thereto offered commitments that ensured the competitiveness of wholesale markets and offered a "potential" for MVNOs to upgrade themselves to MNOs. In H3G/ Orange Austria the commitments ensured an upfront new MVNO entry and lowered entry barriers for "both groups of potential competitors", i.e. MNOs as well as MVNOs. ${ }^{181}$ The commitments offered "the opportunity for a new MVNO to emerge" and also pointed out the potential for MVNOs to upgrade themselves to MNOs. ${ }^{182}$ In Telefónica Deutschland/E-Plus the MNO remedy sought to create a fourth competing MNO. The MBA MVNO remedy sought to generate "aggressive competition" that would offset the loss of competition resulting from the elimination of E-Plus. ${ }^{183}$ The non-MNO remedy sought to make the wholesale market more competitive. In H3G UK/Telefónica Ireland it was expected that the entry of two new MVNOs within a reasonable timeframe, as well as the certainty of Eircom's quick evolution into a credible MVNO host, would ensure vibrant retail and wholesale competition. ${ }^{184}$

Considering the substantial sunk costs in telecoms, 2-3 years may be a very short timeframe to assess the effectiveness of the above-mentioned remedies. However, ex-post studies and emerging evidence from enforcement of the aforementioned

\footnotetext{
178 OECD (2015), pp. 8 and 18.

179 Dewenter and Haucap (2006), pp. 324-326.

180 Ibid.

181 Hutchison 3G Austria/Orange Austria, supra note 86, at para. 539.

182 Ibid., at paras. 540-44.

183 Telefónica Deutschland/E-Plus, supra note 87, at para. 1390.

184 Hutchison 3G Ireland/Telefónica Ireland, supra note 49, at paras. 1022-26.
} 
remedies had a significant influence on the approach of the Commission in subsequent four-to-three mergers.

With reference to TeliaSonera/Telenor, Commission Vestager highlighted the Commission's prohibition decision as good for retaining the competitiveness of the Danish telecoms market. ${ }^{185}$ Considering the significance of the competition concerns, i.e. a substantial impediment to price and innovation-based competition in the Danish telecoms market, in the opinion of competition Commissioner Vestager, herself a Danish citizen, the merger required an "equally significant remedy", which meant the "creation of a fourth MNO". 186

The need for the creation of a fourth MNO was underlined in the light of emerging evidence, including an ex-post econometric study by the Austrian Telecoms regulator, the Bundeswettbewerbsbehörde, highlighting that the four-tothree H3G/Orange Austria merger led to an overall 14-20\% increase in prices in the short term. ${ }^{187}$ However, about 3 years later prices had returned to their pre-merger levels. ${ }^{188}$ The Commission's decision in TeliaSonera/Telenor JV, it seems, was influenced by the short-run price increase in the Austrian market, even though the study found that the MNOs had failed to sustainably increase prices for a long period and that the remedies had failed to ensure market entry for more than 2 years following the merger. ${ }^{189}$

In H3G UK/Telefónica UK the parties submitted a complex set of remedies that went far "beyond the commitments accepted by the Commission in earlier mobile mergers". ${ }^{190}$ The Commission found those commitments to be insufficient to alleviate the competition concerns for the following reasons. The Tesco Mobile commitment was found to be inadequate as it was not an upfront commitment; moreover, the capacity share proposed offered Tesco a very limited ability to increase its market share. ${ }^{191}$ The network sharing commitment was found to be inadequate to effectively address the Commission's key concerns resulting from misalignment of interests between the merged entity and its network sharing partners. ${ }^{192}$ This misalignment of interests was expected to generate significant uncertainties, delays and, subsequently, overall low industry-wide investments. The commitment failed to address with a requisite degree of certainty whether it could effectively alleviate the resulting harm to the other two MNOs (i.e. Vodafone and $\mathrm{BT} / \mathrm{EE}) .{ }^{193}$ The Commission identified challenges with regard to the wholesale commitment, as it was merely an offer to enter into an agreement with a new MVNO. Expressions such as old and new MVNOs, benchmarking and unattractive pricing to MVNOs were defined ambiguously in the proposed commitments. There

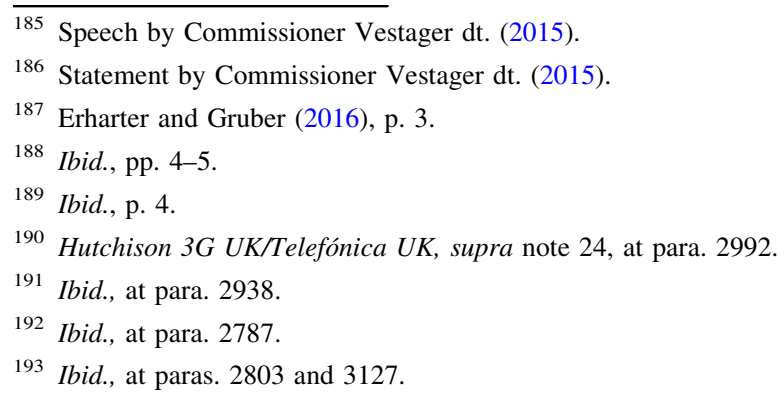


were also uncertainties concerning wholesale access to MVNOs, meaning it was uncertain as to which of the two networks were likely to host MVNOs after the merger. ${ }^{194}$ As the commitments failed to address the competitive concerns, the Commission prohibited the merger. ${ }^{195}$

In H3G Italy/WIND/JV the "fix-it-first remedy" identified Iliad as a clear purchaser, and this was particularly welcomed by the Commission. ${ }^{196}$ It helped the Commission to accurately assess the effectiveness of the remedy, as Iliad met the "standard purchaser requirements" specified in the remedies notice. ${ }^{197}$ Iliad qualified as a suitable purchaser because it was independent from the parties, had sufficient expertise and financial resources to function as an MNO, and neither gave rise to nor was likely to create any additional competition concerns. ${ }^{198}$

It may be true that structural remedies, like a surgical operation, clearly address the issue of market structure; however, behavioural remedies can also offer the desired "structural" solution by having an effect-based impact on the market equivalent to an effective medicine. ${ }^{199}$ It appears that this has been the principle difference in the approaches of the two Commissioners. For Commissioner Vestager mere access is not sufficient, a clear divestiture is a more appropriate remedial design.

\section{Conclusion}

Plus ça change, plus c'est la même chose. ${ }^{200}$

The famous French saying meaning that the more things change, the more things remain the same is a very apt description of trends in the Commission's assessment of telecoms mergers. In Gencor/Lonrho the Court of First Instance (now the General Court) held that the categorisation of remedies as structural or behavioural was immaterial, instead it was their ability to prevent the "emergence or strengthening of a dominant position" that was significant. ${ }^{201}$ Moreover, for remedies to be effective they should "just" preserve the pre-merger conditions of competition without affecting any resulting merger-related efficiency gains. ${ }^{202}$

Following the conditional clearance of a merger that reduced the number of MNOs from four to three in the EU's largest market, Telefónica Germany/E-Plus was seen as a signal that the European Commission was willing to accept the reduction of the number of MNOs in a Member State from four to three, provided

\footnotetext{
194 Ibid., at paras. 3143-3148.

195 Ibid., at paras. 3149-51.

196 Hutchison 3G Italy/Wind/JV, supra note 25, at para. 1798.

197 Ibid., at para. 1800.

198 Ibid., at paras. 1800-04.

199 Newton and Parker (2005).

200 Karr (1866).

201 GC, Gencor v. Commission, at paras. 318-20.

202 Parker and Balto (2000).
} 
that suitable remedies were proposed that preserved the conditions of competition in the relevant national market.

Perusal of recent telecoms mergers provides a different narrative, and it appears that in future the Commission may be unwilling to accept remedies that "merely" offer the potential to make wholesale markets more competitive or ensure an upfront MVNO entry or an MNO entry over time. Interestingly, the Commission could foresee the challenges associated with the implementation of MNO remedies, even though it had previously given conditional clearance to four-to-three mergers. In Telefónica Deutschland/E-Plus even though the Commission recognised that the MNO remedy was unlikely to be implemented it eventually did accept that remedy, on the grounds that the remedy in combination with the "upcoming frequency auction" by the German regulator (the Bundesnetzagentur) was helpful for keeping the door open for potential future entrants to the German market. ${ }^{203}$ Ex-post analysis highlights that the parties eventually failed to enter into an agreement with a potential entrant. Telefónica Deutschland finally signed an agreement with Drillisch, an MVNA, to sell it a minimum of $20 \%$ of its future mobile network via MBA, with a possibility of selling another $10 \%$ if Drillisch wished to purchase it. ${ }^{204}$

In H3G Italy/WIND/JV the identification of an upfront buyer, Iliad, an operating MNO in the neighbouring French market - that met the "standard purchaser requirements" of independence, possessed the requisite financial resources and expertise, and had viable incentives to evolve into an $\mathrm{MNO}$ - played a key role in the Commission's conditional clearance.

However, divestiture is not as risk-free as the current approach of the Commission to remedy design may suggest. ${ }^{205}$ In the same way, behavioural remedies are not without their own set of limitations. Continuous post-merger intervention in a market over a period of time can adversely affect the competitive process. ${ }^{206}$ A recurrent challenge with divestitures is significant deterioration of the divested assets to undermine its competitive strength. ${ }^{207}$ To solve this problem in the recent telecoms mergers the Commission insisted on an up-front buyer or fix-itfirst remedy. In future mobile mergers commitments that clearly preserve four MNOs through divestment and the identification of an "upfront buyer" may play a decisive role in receiving the approval of the Commission.

Due to the very special nature and characteristics of the sector, such as the presence of network effects and oligopolistic market structures and the innovationled nature of the industry, competition authorities face significant challenges in assessment of anti-competitive effects of telecoms mergers. ${ }^{208}$ The argument holds water from the first wave of telecoms mergers in the 1990s, when the EU and US competition authorities were first confronted with substantial challenges in assessing every step of a merger review - from the definition of the relevant

\footnotetext{
${ }^{203}$ Telefónica Deutschland/E-Plus, supra note 87, at para. 1382.

${ }^{204}$ Keil (2014).

205 Papandropoulos and Tajana (2006), p. 447.

206 Ezrachi (2005), p. 3.

207 ICN Merger Remedies Review Project (2005), pp. 8-10.

${ }^{208}$ Svetlicinii (2008), p. 37.
} 
market to defining relevant theories of harm to the designing of suitable remedies ${ }^{209}$ - to the more recent wave discussed in this article. If there were any lessons from the remedies in the first wave of mergers, it was the challenge in "integrated network industries" to divest without adversely impacting the competitive strength of the buyer. ${ }^{210}$ In WorldCom/MCI the parties sold MCI's Internet business to Cable \& Wireless, the largest divestiture ever and a remedy at the time well accepted by both the EU and US competition authorities. ${ }^{211}$ However, the remedies subsequently failed to preserve the conditions for competition in the relevant market for universal Internet connectivity. ${ }^{212}$ The failure of remedies in WorldCom/MCI led the Commission to reject similar proposed structural remedies in WorldCom MCI and Sprint and prohibit the merger. ${ }^{213}$

Assessed against this backdrop, the remedies in $\mathrm{H} 3 \mathrm{G} / \mathrm{WIND} / \mathrm{JV}$ went a step further: as first in addition to the divested assets they involve the transfer of customers to a new MNO entrant. That implies that in addition to the integration of networks and infrastructure the remedies add substantially to the transaction costs in terms of gaining the consent of customers.

Second, product differentiation limits the effectiveness and efficiency of structural remedies, such as carve-outs and divestitures, remedies that transfer assets from the merged parties to a third entity. ${ }^{214}$ This is because the amount of assets that need to be divested to avert any post-merger price increase has a positive correlation with the degree of product differentiation. ${ }^{215}$

Third, considering the dynamic nature of the telecommunications sector, the Commission's attempt to identify trends with absolute certainty may, in the long run, prove detrimental to innovation-led competition. Whether F/M mergers, as distinguished from mobile-only mergers, offer firms a sustainable competitive advantage is a case in point. That is best underlined by the way in which the European Commission and the UK's CMA approached the H3G/Telefónica UK merger and how the industry analysed that deal. Technically $5 \mathrm{G}$ is expected to play a central role in facilitating convergence, by offering F/M operators the advantage of "integrating small cells and Wi-Fi networks into existing macro-cell RANs". 216 As standardiation of $5 \mathrm{G}$ is still in its nascent stage, there seems to be an element of uncertainty as to whether, strategically speaking, F/M players would have an advantage over mobile-only players in the near future. ${ }^{217}$ Taking that uncertainty into consideration, in the recently approved EE/BT merger the CMA expressed

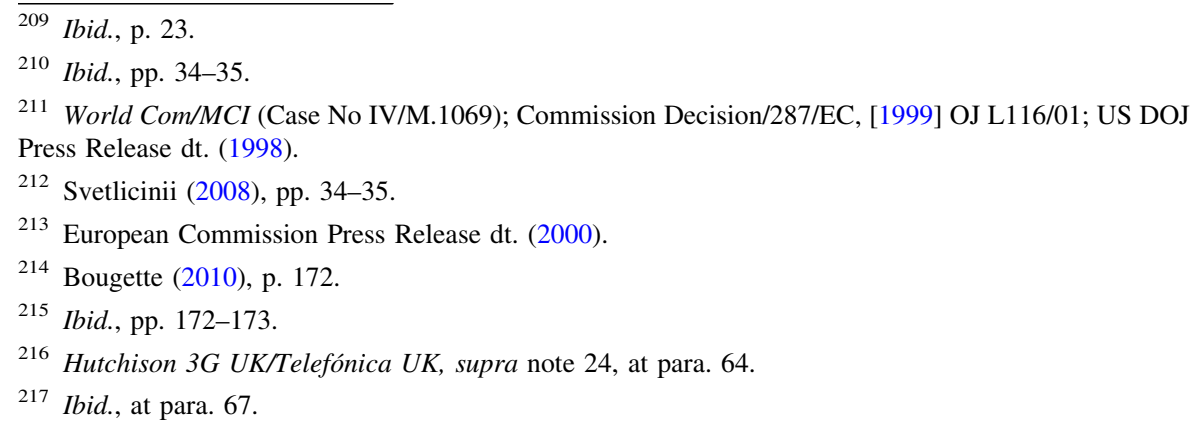


scepticism as to whether F/M players have an advantage over the fixed-only or mobile-only service providers. ${ }^{218}$

In the not too distant future growth will come through offering "bundled services" and different permutations and combination of bundles, as distinguished from mere mobile telecommunications and data subscription services. ${ }^{219}$ Additionally, infrastructure-led competition is a long-term objective - and the determination of the optimum-level of that is a subjective issue which depends upon, amongst other factors, on the future evolution of market shares and the associated expectations of the operators to make reasonable returns on their investments. ${ }^{220}$ So far, in the UK F/M operators have had very limited success, with the largest UK fixed line operator gaining only $4 \%$ of the mobile market. ${ }^{221}$ However, market research indicates that this is expected to change by 2020, as quad-play revenues are expected to triple, as opposed to double-play subscriptions, which are falling. ${ }^{222}$ The UK's Ofcom also expects there may be F/M and network convergence over time, as end-user devices increasingly switch to wireless and networks use fibre to offer the necessary network capacity. ${ }^{223}$ In an emerging convergence-led services market the BT/EE merger positions BT well to cross-sell services, which, along with its strong fibre and $4 \mathrm{G}$ network, may endow it with an unparalleled competitive strength. Telecommunications firms, such as BT, Sky, TalkTalk, Virgin Media and Vodafone, do not see any MNO or MVNO as their strongest competitor. Instead, for them competition emerges from operators that have the ability to offer the most competitive "bundled service offerings". ${ }^{224}$

Nonetheless, in $\mathrm{H} 3 \mathrm{G}$ UK/Telefónica UK the European Commission took a different approach. The Commission, based on market study and the submissions from Ofcom and the CMA, was of the opinion that over the next 2-3 years acceptance of bundles with a mobile component was not expected to see a significant increase and therefore decided to prohibit the merger. ${ }^{225}$

Sluggish uptake due to consumer inertia may be partially explained by the bounded rationality of the average consumer. ${ }^{226}$ In the long run neo-classical economics suggests that rationality would prompt consumers to switch to the most value-optimising alternative. In a sector which faces long-term investments and substantial sunk costs, decisions premised on short-run consumer behaviour have the potential to adversely impact the process of dynamic competition.

As regards merger remedies, there is no text book authority or clear empirical evidence that may support the superiority of one type of remedies over another. From the dimension of property rights, whereas structural remedies change the

\footnotetext{
218 UK CMA, BT/EE, at para. 14.147.

219 Knoll (2008), p. 163; Arthur di Little (2017); Pyramid Research (2015).

220 Garzaniti and O'Regan (2010), p. 60.

221 Enders Analysis (2015), Hutchison 3G UK/Telefónica UK, supra note 24, at para. 76.

222 Blackwell et al. (2016).

223 Hutchison $3 G$ UK/Telefónica UK, supra note 24, at paras. 701-702, UK Ofcom (2015).

224 Blackwell et al. (2016).

225 Hutchison 3G UK/Telefónica UK, supra note 24, at paras. 77, 91.

226 Drexl (2016), p. 10; Ezrachi (2017), pp. 60-62.
} 
ownership of property rights, behavioural remedies "only" define limits by setting constraints to the property rights or behaviour of the merging parties. ${ }^{227}$ The only conclusion we can safely draw is that the choice and design of remedies is a casespecific question, which is subject substantially to the relevant market and theory of harm under deliberation. ${ }^{228}$ This article makes the following contribution to this debate that the distinctive nature and the level of convergence and innovation in the telecommunications sector, which offers the potential to disrupt the very limits of the relevant markets, merits imperative consideration in the design of remedies to promote competition and innovation. Additionally, the observation, though made with reference to the ever-converging telecommunications sector, holds with equal rigour across the entire Information Communications and Technology sector - an issue dealt with in greater depth in the second part of this article.

Acknowledgements Open access funding provided by Max Planck Society. I am grateful to Prof. Dr. Josef Drexl (Director of the Max Planck Institute), Prof. Dr. Peter Picht (University of Zurich) and Prof. Dr. Subhashish Gupta (the Indian Institute of Management, Bangalore) for their comments and valuable suggestions on my research. The views expressed in this article, and any errors or omissions, are my own.

Open Access This article is distributed under the terms of the Creative Commons Attribution 4.0 International License (http://creativecommons.org/licenses/by/4.0/), which permits unrestricted use, distribution, and reproduction in any medium, provided you give appropriate credit to the original author(s) and the source, provide a link to the Creative Commons license, and indicate if changes were made.

\section{References}

\section{EU Regulations}

Regulation (EC) No 2887/2000 of the European Parliament and of the Council of 18 December 2000 on unbundled access to the local loop [2000] OJ L 336/4

\section{EU Guidelines and Notices}

Commission Notice on remedies acceptable under Council Regulation (EC) No 139/2004 and under Commission Regulation (EC) No 802/2004 [2008] OJ C267/01

Guidelines on the assessment of horizontal mergers under the Council Regulation on the control of concentrations between undertakings, [2004] OJ C31/05

\section{US Guidelines}

Horizontal Merger Guidelines, U.S. Department of Justice and the Federal Trade Commission [2010]

\footnotetext{
227 Papon (2009), p. 38

228 Ibid., p. 48.
} 


\section{Case Law}

\section{General Court}

Gencor v. Commission (Case T-102/92) [1999] ECR II-753

CK Telecoms UK Investments v European Commission (Case T-399/16) [2016] OJ C371/12. (Currently pending appeal before the General Court)

\section{European Commission}

T-Mobile/Orange (Case No COMP/M.5650) [2010] OJ C108/03

Hutchison 3G Austria/Orange Austria (Case COMP/M.6497) [2013] OJ C224/12

Hutchison $3 G$ Ireland/Telefónica Ireland (Case No COMP/M6992) [2014] OJ C264/6

Telefónica Deutschland/E-Plus (Case M.7018) [2015] OJ C086/7

TeliaSonera/Telenor/JV (Case M.7419) [2015] OJ C 316/01

Hutchison 3G Italy/Wind/JV (Case M.7758) [2015] OJ C 391/05

Hutchison 3G UK/Telefónica UK (Case M.7612) [2016] OJ C 357/08

Liberty Global/BASE Belgium (Case M.7637) [2016] OJ C141/06

Western Digital/Hitachi (Case COMP/M.6203) [2011] OJ C241/11

Seagate/HDD Business of Samsung (Case COMP/M.6214) [2011] OJ C154/08

World Com/MCI (Case No IV/M.1069) Commission Decision 1999/287/EC OJ L116/01

\section{French Competition Authority}

Avis $\mathrm{n}^{\circ} 08-\mathrm{A}-16$ du juillet 2008 relatif à la situation des opérateurs de réseaux mobiles virtuels(MVNO) sur le marché français de la téléphonie mobile. http://www.autoritedelaconcurrence.fr/user/avisdec. php?numero $=08$ A 16 . Accessed 2 July 2017

\section{Swiss Competition Authority}

Verfügung vom 21 April 2010, betreffend das Zussamenschlussvorhaben 41-0594: France Télécom SA/ Sunrise Communications AG

\section{US Competition Authority}

Department of Justice, Justice Department clears WorldCom/MCI merger after MCI agrees to sell its Internet Business: Largest Divestiture of Company in Merger History (1998). https://www.justice. gov/archive/atr/public/press_releases/1998/1829.htm. Accessed 21 September 2017

\section{UK Competition and Markets Authority}

Competition and Markets Authority, BT Group plc and EE Limited: A report on the anticipated acquisition by BT Group plc of EE Limited (2016). https://assets.publishing.service.gov.uk/media/ 56992242ed915d4747000026/BT_EE_final_report.pdf. Accessed 21 September 2017

\section{Ex-post remedies study (by Austrian Competition Authority)}

Erharter D, Gruber J (2016) The Austrian Market for Mobile Telecommunications Services to Private Customers: An Ex-post Evaluation of the Mergers H3G/Orange and TA/Yesss! https://www.bwb.gv. at/Documents/BWB2016-re-Ex-post\%20evaluation\%20of\%20the\%20mobile\% 20telecommunications\%20market.pdf. Accessed 21 Sept 2017

\section{Books and Articles}

\section{Articles}

Analysis Mason (2017) Market Research Report. Telecoms retail revenue in developed Asia-Pacific will increase to USD 178 billion in 2021 at a CAGR of $0.6 \%$. http://www.analysysmason.com/Research/ Content/Regional-forecasts-/DVAP-interim-Mar2017-RDRP0-RDDG0/. Accessed 21 Sept 2017

Arpaci-Dusseau RH, Arpaci-Dusseau AC (2014) Operating systems: three easy pieces. http://pages.cs. wisc.edu/ remzi/OSTEP/. Accessed 21 Sept 2017

Arthur di Little (2017) Major strategic choices ahead of TelCos: reconfiguring for value. how digitalization will impact telecommunication operators' configuration. http://www.adlittle.com/ downloads/tx_adlreports/ADL_Strategic_Choices.pdf. Accessed 21 Sept 2017

Bar A (2014) Debunking the myths behind multi-pay. Telecom Tech. https://www.telecomstechnews. com/news/2014/mar/20/debunking-myths-behind-multi-play/. Accessed 21 Sept 2017 
Bavasso A, Long D (2012) H3G/Orange Austria - mobile consolidation and regulatory reaction. Competition Policy International 2012. https:/www.competitionpolicyinternational.com/assets/ Uploads/Europe12-20-2012-final-2.pdf. Accessed 21 Sept 2017

Bennett A (2013) Lycamobile CEO Milind Kangle on building a $£ 120$ million British telecoms empire. Huffiington Post. http://www.huffingtonpost.co.uk/2013/09/02/lycamobile-milind-kangle_n_ 3720471.html. Accessed 21 Sept 2017

Blackwell J, Mercer D, Sephton J (2016) UK multiple bundle subscriptions driving revenue growth. Strategy Anal. https:/www.strategyanalytics.com/strategy-analytics/news/strategy-analytics-pressreleases/strategy-analytics-press-release/2016/07/28/strategy-analytics-uk-multiplay-bundlesubscriptions-driving-revenue-growth\#.WcOEqNKCxdg. Accessed 21 Sept 2017

Bougette P (2010) Preventing merger unilateral effects: a Nash-Cournot approach to asset divestitures. Res Econ 64:162-174

Bourreau M, Doğan P (2001) Regulation and innovation in the telecommunications industry. Telecommun Policy 25(3):167-184

Brito D, Pereira P (2010) Access to bottleneck inputs under oligopoly: a prisoner's dilemma? South Econ J 76(3):660-677

Buettner T (2016) Closeness of competition from an economic perspective. J Eur Compet Law Pract 7(10):690-695

Cohen WM, Levinthal DA (1990) Absortive capacity: a new perspective on learning and innovation. Adm Sci Q 35(1):128-152

Drexl J (2016) Economic efficiency versus democracy: on the potential role of competition policy in regulating digital markets in times of post-truth politics. Max Planck Institute for Innovation and Competition and Research Paper No. 16-16. https://papers.ssrn.com/sol3/papers.cfm?abstract_id= 2881191. Accessed 21 Sept 2017

Duso T, Neven DJ, Röller LH (2003) The political economy of European merger control: evidence using stock market data. Wissenschaftszentrum Berlin Discussion Paper FS IV 02-34r. http://dev3.cepr. org/meets/wkcn/6/6607/papers/neven.pdf. Accessed 21 Sept 2017

Enders Analysis (2015) UK broadband, telephony and pay TV trends Q3 2014, quad play and convergence focus. http://www.endersanalysis.com/content/publication/uk-broadband-telephonyand-pay-tv-trends-q3-2014-quad-play-and-convergence-focus. Accessed 21 Sept 2017

European Commission (2000) Commission prohibits merger between WorldCom MCI and Sprint. http:// europa.eu/rapid/press-release_IP-00-668_en.htm. Accessed 21 Sept 2017

European Commission (2011) Mergers: commission clears proposed acquisition of Samsung's hard disk drive business by seagate technology. http://europa.eu/rapid/press-release_IP-11-1213_en.htm. Accessed 21 Sept 2017

Ezrachi A (2005) Under (and over) prescribing of behavioural remedies. University of Oxford, Centre for Competition Law and Policy Working Paper No. (L) 13/5. https://papers.ssrn.com/sol3/papers. cfm?abstract_id=913773. Accessed 21 Sept 2017

Ezrachi A (2017) Sponge. J Antitrust Enforc 5(1). https://academic.oup.com/antitrust/article/5/1/49/ 2525569/Sponge. Accessed 21 Sept 2017

Fauver JC, Ramanarayanan S (2016) Challenges for economic analysis of mergers between potential competitors. Antitrust 30(3). http://awards.concurrences.com/articles-awards/business-articlesawards/article/challenges-for-economic-analysis-of-mergers-between-potential-competitors. Accessed 21 Sept 2017

Garside J (2011) Lebara co-founder made virtual phone network a real money maker. The Guardian. https://www.theguardian.com/business/2011/nov/17/lebara-co-founder-yoganathan-ratheesaninterview. Accessed 21 Sept 2017

Grajek M, Kretschmer T (2012) Identifying critical mass in the global cellular telephony market. Int J Ind Organ 30(6):496-507

Green R (2015) The future of converged services-will it be triple-play or quad-play that comes out on top? Telecoms Tech. https://www.telecomstechnews.com/news/2015/oct/06/future-convergedservices-will-it-be-triple-play-or-quad-play-comes-out-top/. Accessed 21 Sept 2017

Groene F, Navalekar A, Coakley MK (2017) An industry at risk: commoditization in the wireless telecom industry. Price Waterhouse Coopers. https://www.strategyand.pwc.com/reports/industry-at-risk. Accessed 21 Sept 2017

ICN Merger Working Group: Analytical Framework Subgroup (2005) Merger remedies review project: report for the fourth ICN annual conference. http://www.internationalcompetitionnetwork.org/ uploads/library/doc323.pdf. Accessed 21 Sept 2017 
Jungermann F (2015) Plan B: avoid the merger-to-no-merger journey. http://tefficient.com/plan-b-avoidthe-merger-to-no-merger/. Accessed 21 Sept 2017

Keil O (2014) Drillisch AG: EU Kommission bestätigt MBA MVNO Vertrag zwischen Drillisch und Telefonica Deutschland. Handelsblatt. http://ircenter.handelsblatt.com/websites/ircenter_ handelsblatt10/German/9020/news.html?newsID=1421789\&companyDirectoryName=drillisch. Accessed 21 Sept 2017

de Launay H (2014) Presque 800 MVNO dans le monde, mais quasiment aucun en Afrique. A quand le développement des MVNO sur le continent. TIC \& Telecom. http://www.agenceecofin.com/avis-dexpert/1801-16794-presque-800-mvno-dans-le-monde-mais-quasiment-aucun-en-afrique-a-quandle-developpement-des-mvno-sur-le-continent. Accessed 21 Sept 2017

Lee S, Chan-Olmsted SM, Ho HH (2008) The emergence of mobile virtual network operators (MVNOs): an examination of the business strategy in the global MVNO market. Int $\mathrm{J}$ Media Manag 10(1):10-21

Lee S, Lee S (2008) Multiple play strategy in global telecommunication markets: an empirical analysis. Int J Mob Mark 3(2):44-53

Manigrassi L, Ocello E, Staykova V (2016) Recent developments in telecoms mergers. Compet Merger Brief 3(2016): 1-8

Newton C, Parker D (2005) Surgery or medicine? The use of behavioural remedies in merger control. Front Econ. https://www.frontier-economics.com/documents/2014/05/surgery-or-medicine-frontierbulletin.pdf. Accessed 21 Sept 2017

OECD (2015) Wireless market structures and network sharing. DSTI/ICCP/CISP (2014) 2/FINAL. http:// www.oecd.org/officialdocuments/publicdisplaydocumentpdf/?cote=DSTI/ICCP/CISP(2014)2/ FINAL\&docLanguage $=$ En. Accessed 21 Sept 2017

Ofcom (2014) Cost and value of communications services in the UK. https://www.ofcom.org.uk/_data/ assets/pdf_file/0023/53735/cost_value_final.pdf. Accessed 21 Sept 2017

Ofcom (2015) Strategic review of digital communications. https://www.ofcom.org.uk/_data/assets/pdf_ file/0018/58410/citizens_advice.pdf. Accessed 2 Jul 2017

Oliver C (2015) Brussels to probe proposed TeliaSonera and Telenor joint venture. Financ Times. https:// www.ft.com/content/7da56dd0-ddf8-11e4-9d29-00144feab7de. Accessed 21 Sept 2017

Papandropoulos P, Tajana A (2006) The merger remedies study-in divestiture we trust? Eur Compet Law Rev 27(8):443-454

Parker RG, Balto DA (2000) The evolving approach to merger remedies. Antitrust Rep. https://www.ftc. gov/public-statements/2000/05/evolving-approach-merger-remedies. Accessed 21 Sept 2017

Papon S (2009) Structural versus behavioural remedies in merger control. Eur Compet Law Rev Case Case Anal 30(1):36-48

Popoviü D (2010) Merger remedies and regulatory measures in the EU electronic communications sector: a critical assessment. Eur Bus Organ Law Rev 10(4):575-594

Proposal for a Directive of the European Parliament and of the Council Establishing the European Electronic Communications Code (Final) COM (2016) 590. https://ec.europa.eu/digital-singlemarket/en/news/proposed-directive-establishing-european-electronic-communications-code. Accessed 21 Sept 2017

Pyramid Research (2015) Multi-play services: bundling growth and strategies beyond traditional quadruple-play. https://www.reportbuyer.com/product/3467261/multiplay-services-bundlinggrowth-and-strategies-beyond-traditional-quadruple-play.html. Accessed 21 Sept 2017

Schubert S (2016) Mobile fixation? A review of recent EC decisions in the telecoms sector. Compet Policy Int 2(1). https://www.competitionpolicyinternational.com/mobile-fixation-a-review-ofrecent-ec-decisions-in-the-telecoms-sector/. Accessed 21 Sept 2017

Stoyanova-Sieber M (2013) The Orange-H3G merger and the new regulatory paradigm for a single telecoms market. Eur Compet J 2(9):431-463. Accessed 21 Sept 2017

Svetlicinii A (2008) Telecommunications mergers under the EC competition law and US antitrust law: substantive assessment and procedural cooperation. Camb Stud Law Rev 4(1):22-39

de Streel A (2011) La régulation des industries de réseau en Belgique. Reflets et Perspectives de la Vie Économique 3:73-92. https://www.cairn.info/revue-reflets-et-perspectives-de-la-vie-economique2011-3-page-73.htm. Accessed 21 Sept 2017

Thomas D (2015) Danish telecoms merger shelved after competition concerns. Financ Times. https:// www.ft.com/content/c935224c-5853-11e5-97e9-7f0bf5e7177b. Accessed 2 Jul 2017. Accessed 21 Sept 2017 


\section{Books}

Cave M (2004) Economic aspects of the new regulatory regime for electronics communications services. In: Buigues PA, Rey P (eds) The economics of antitrust and regulation in telecommunications: perspectives for the new European regulatory framework. Edward Elgar, Cheltenham, pp 27-44

Dewenter R, Haucap J (2006) Incentives to licence mobile virtual network operators. In: Dewenter R, Haucap J (eds) Access pricing: theory and practice. Elsevier Science, Amsterdam, pp 305-325

Fudenberg D, Tirole (1991) Game theory. The MIT Press, Cambridge

Garzaniti LGHF, O'Regan M (eds) (2010) Telecommunications, broadcasting and the internet: EU competition law and regulation, 3rd edn. Sweet \& Maxwell, London

Huveneers C, de Streel A (2009) Quel État pour quelles Performances Économiques dans le Champ de la Régulation Sectorielle? Une Introduction. In: CIFOP (éd) Quel État pour quelle performance économiques, Actes du $18^{\mathrm{e}}$ Congrès des économistes belges de langue française, pp 335-361

Karr JBA (1866) Les Guêpes (3ème sèrie). Michel Lévy Frères, Paris

Knoll S (2008) Cross-business synergies: a typology of cross-business synergies and a mid-range theory of continuous growth synergy realization. Springer Gabler, Wiesbaden

Lindsay A, Berridge A (2012) The EU merger regulation: substantive issues, 3rd edn. Sweet \& Maxwell, London

Myerson RB (1997) Game theory: analysis of conflict. Harvard University Press, Cambridge

Nenova MB (2007) EC electronic communications and competition law. Cameron May, London

Pagani M (2003) Multimedia and interactive digital TV: managing the opportunities created by digital convergence, 2nd edn. IGI Publishing Hershey, Hershey

Posner RA (1976) Antitrust law: an economic perspective. University of Chicago Press, Chicago

Rey P (2004) Collective dominance and the telecommunications industry. In: Buigues PA, Rey P (eds) The economics of antitrust and regulation in telecommunications: perspectives for the new european regulatory framework. Edward Elgar, Cheltenham, pp 91-113

\section{Speeches and Statements}

Tirole J (1999) “The Institutional Infrastructure of Competition Policy" (Roundtable on New Comparative Economic Systems, World Bank-CAE Conference on Governance, Equity and Global Markets, Paris, 29 June 1999). http://citeseerx.ist.psu.edu/viewdoc/download?doi=10.1.1.201. $7825 \&$ rep=rep1\&type=pdf. Accessed 21 Sept 2017

Vestager M (2015) "Statement by Commissioner Vestager on announcement by Telenor and TeliaSonera to withdraw the proposed merger" (Brussels, 11 September 2015). http://europa.eu/rapid/pressrelease_STATEMENT-15-5627_de.htm. Accessed 21 Sept 2017

Vestager M (2015) "Competition in Telecom Markets" (42nd Annual Conference on International Antitrust Law and Policy, Fordham University, 2 October 2015). https://ec.europa.eu/commission/ commissioners/2014-2019/vestager/announcements/competition-telecom-markets_en. Accessed 21 Sept 2017 